\title{
Vikings and Tigers: Finland, Sweden, and adoption of environmental technologies in Southeast Asia's pulp and paper industries ${ }^{1}$
}

\author{
by \\ David A. Sonnenfeld \\ Department of Sociology \\ Washington State University \\ 1671 University Drive \\ Richland, WA 99352-1671 \\ USA \\ E-mail: sonn@wsu.edu
}

Cite: Sonnenfeld, David A. (1999). "Vikings and Tigers: Finland, Sweden, and adoption of environmental technologies in Southeast Asia's pulp and paper industries." Journal of World-Systems Research http://jwsr.ucr.edu/ 5: 26-47.

(C) 1999 David A. Sonnenfeld.

[Page 26]

Journal of World-Systems Research

\begin{abstract}
This paper examines structural dimensions of the influence of core-periphery relations on adoption of environmental technologies in newly industrializing countries (NICs), using Nordic involvement in development of Southeast Asian pulp manufacturing in the late 1980s and early 1990s as a case study. Contrary to conventional wisdom, Southeast Asia was one of the first places in the world to employ new cleaner technologies in pulp and paper manufacturing. How did this happen? This paper argues that adoption of these technologies was influenced by dynamics within the world-system combined with the intentional actions of firms, states, and social movements over a 30 -year period. The paper concludes that diffusion of the new environmental technologies is resulting in cleaner production in the periphery even while being part of a trend toward increased polarization between core and peripheral states, economies, and firms. Data were gathered from fieldwork in Southeast Asia from 1993-96; correspondence with Nordic firms, organizations and individuals; attendance and interviews at industry trade shows; and use of available data. Portions of the paper are derived from a larger study of adoption of environmental technologies in the pulp and paper industries of Southeast Asia and Australia.
\end{abstract}

"I sell the same stuff here as we sell anywhere in the world ... it's economics that drives it. How they operate it, what they do when the wastewater treatment facility breaks down, that I can't say ... maybe they keep on operating, get it fixed in a week. All I know is the equipment's there.

-- Singapore-based sales representative of a Nordic technology firm.

\section{Introduction}

In the early 1990s, Southeast Asian pulp firms adopted world-class cleaner production technologies, defying conventional wisdom that "Third World" 
countries were simply sites for "First World" manufacturing activities to run away to, to avoid increasingly stringent environmental controls at home -- the so-called "pollution haven thesis"(see Leonard 1988; see also Eskeland and Harrison 1997). How did this come to take place? This paper maintains that Southeast Asian pulp firms' adoption of new, more environmentally-friendly pulping and bleaching technologies was a product of structural dynamics within the world-system combined with the intentional actions of firms, states, and social movements in Nordic Europe (including especially Finland, Sweden and Norway) and Southeast Asia over at least a 30-year period.

After Raumolin $(1984 ; 1990 ; 1991 ; 1992)$, I argue that Finnish and Swedish corporate and state interests -- modern-day "Vikings" -- have pursued a strategy of global specialization in forest industry technology as part of an effort to maintain competitive position within the structure of the world-system. In the late 1980s and early 1990s, under conditions of global recession compounded by political restructuring and realignment in Europe, Nordic countries targeted forest industry process technologies as part of a broader effort to expand high value-added exports to the newly industrializing countries of Southeast Asia -- the new "Tiger" economies. Southeast Asia was one of the few regions of the world booming at the time.

This paper begins with a summary of recent world-systems theory on industry, environment \& the periphery, outlines the history of development of Finland and Sweden's specialization in forest industry technology, analyzes the establishment of "Viking" presence among the "Tigers" of Southeast Asia, examines conditions under which Southeast Asian firms adopted new, Nordic pulp and paper technologies, and discusses implications of these dynamics for world-systems theory. Data for the study were gathered from fieldwork in Southeast Asia from 1993-96, correspondence with Nordic firms, organizations and individuals, attendance and interviews at industry trade shows, and use of available data.

\section{Core, Periphery and Environment}

In Global Formation, Chase-Dunn (1989) suggests a number of ways in which coreperiphery relations are changing in the course of the establishment of a "new international division of labor" (NIDL). Certain, especially more labor-intensive, forms of industrial production have been shifting from core to peripheral countries in the world-system. This shift does not alter fundamental hierarchies in the world-system, however. As Arrighi and Drangel (1986) argue, the relative composition of core, semiperipheral, and peripheral components of the world-system remain largely unchanged. This is due to the concentration of research and development, mass marketing, and other high value -added nodes in the commodity chain remaining disproportionately in the core (Chase-Dunn and Hall 1997; Gereffi and Korzeniewicz 1990; Wallerstein 1979) .

With the shift of industrial activity -- the "muscles and nerves" of the world economy -to the periphery, relations between core and periphery change accordingly (Arrighi 1985, cited in Arrighi and Drangel 1986, p. 57). Increasingly, core countries specialize in "brain" activities (ibid.), providing finance, technology/capital goods, and management 
skills as needed to the rest of the world-system. Semiperipheral and weaker core countries must continually scramble to keep from "falling down" in the hierarchy of the world-system, and are particularly motivated to specialize, compete, and aggressively export key factors of domestic comparative advantage to all corners of the globe (Wallerstein 1979). Global economic crises are times of opportunity for weaker core and semiperipheral countries to increase their share of world value-added (ibid.).

[Page 27]

Journal of World-Systems Research

While peripheral areas have historically been locations of extraction of raw materials for export to the more capital-intensive core, for use in manufacturing, increasingly, both first-level processing and manufacture of intermediate goods takes place in the periphery. Today, not only are labor-intensive consumer goods produced in the periphery, but also capital-intensive manufacturing takes place there, such as oil refining, chemical processing, and metallurgy. Labor costs remain a factor for basic industry in the periphery, but more for extraction and transportation of raw materials than for the limited amounts of skilled labor used in capital-intensive production. ${ }^{4}$ Locating manufacturing near sources of primary raw materials can help minimize transportation costs.

Other recent world-systems scholarship analyzes environmental dimensions of peripheral industrialization. Bunker and Ciccantell (Bunker and Ciccantell 1995, p. 3), argue that increasing control of resource extraction in the periphery is an essential feature of efforts by "rising hegemons" to advance standing in the world-system. Hornborg (1988, p. 174) places nature alongside labor as an essential ingredient of the world-system. Advances in technology, he suggests, create new ways for the core to redistribute expropriation of natural resources across space and time. Chew (1997, pp.388 -389), posits that the shift of industrial production from core to periphery is a result of ecological degradation in the core combined with availability of inexpensive natural resources and low-wage labor in the periphery, with "the outcome for Nature [remaining] the same..."

The global pulp and paper industry provides an interesting case in core-periphery relations, industrialization and the environment. Historically, pulp and paper production was concentrated in North America, Europe, and Japan, locations also of the lions shares of paper consumption. In recent years, pulp and paper production has moved increasingly to the periphery and semi-periphery, especially in South America and Southeast Asia, where, as suggested by Chew's (1997) analysis, inexpensive resource costs allow the manufacture of pulp and paper more cheaply than anywhere else on the planet. Pulp and paper production areas in the North, then, are facing increasing competition from the South. Northern countries which held comparative advantage in forest industries have been pressed to include more "value-added" services, including the development and manufacture of new process technologies. 
Finland and Sweden, both historic centers of forest industry production in Europe, have been among the most successful in making a shift in the new international division of labor to forest industry consulting services and pulp and paper technology development. The forward-looking practices of Nordic governmental and non-governmental organizations, technology firms, and research centers, in developing new, cleaner production technologies increased global demand for those technologies, including in Southeast Asia.

This is one point at which earlier analyses of relations between the world-system and environment may be furthered. For multinational corporations and core states not only are vehicles of environmental destruction (as posited, e.g. by Bergesen and Parisi 1997), but also may be agents of environmental advancement. Which aspect is dominant for particular industries and locations is an empirical question, addressed here for Southeast Asia's pulp and paper industries. Or, as Arrighi and Drangel's (1986) analysis may suggest, the core-periphery hierarchy may be heightened in the course of peripheral industrialization, regardless (or even because) of the adoption of clean technologies. How do these dynamics play out in the case of the "Vikings and Tigers" -- Nordic involvement in the development of Southeast Asia's pulp and paper industries?

[Page 28]

Journal of World-Systems Research

\section{Historical Dynamics of the World-System}

Finland and Sweden have long had comparative advantages in forest industries and related industrial process technologies. A century ago, both countries were among the more peripheral states of Europe. ${ }^{5}$ Today both have leveraged human and natural resources and proximity to major European political and economic powers to develop substantial industrial, technological, and intellectual capabilities, rising into the ranks of the core states within the world-system. According to one prominent account, Sweden has been in the core since at least 1938, while Finland is a more recent arrival (Arrighi and Drangel 1986).

Finland's machine industry got started in the 19th century, while a territory within the Russian empire, producing ships for trading and machinery for natural resource bas ed industry in the region, especially forestry and mining (Laakso 1998). During World War I, the Ahlström Company manufactured armaments for Imperial Russian troops. Granted independence in 1917 with the breakup of the Czarist empire, much of the course of Finland's development in the 20th century was shaped by its relations with Soviet Russia. In World War II, Finland sided with Nazi Germany, who engaged Finland's machine industry in reconditioning captured heavy military equipment (Ahlström 1949; 1963; 1994a). 


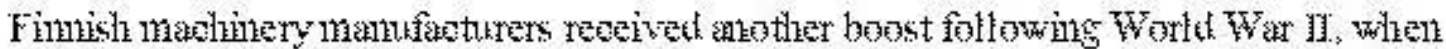
employed by the Finish gorenment to jrovide leawy equimment to the LSSR as part of

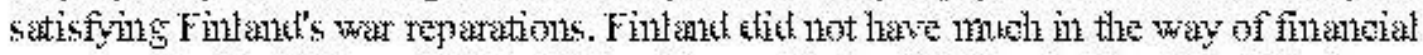

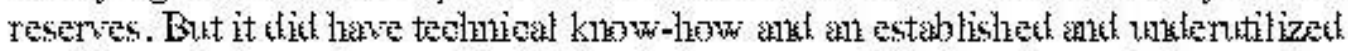

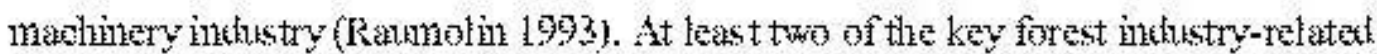

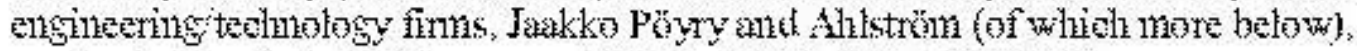

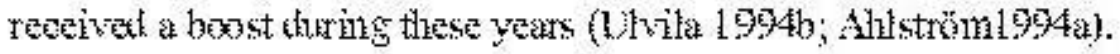

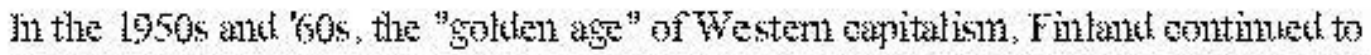

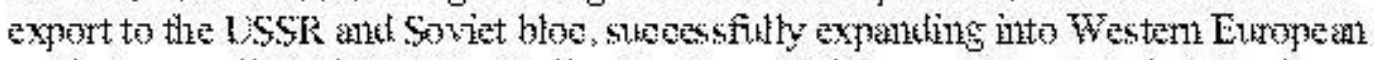

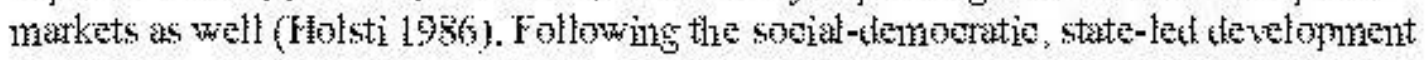

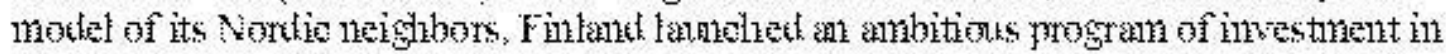

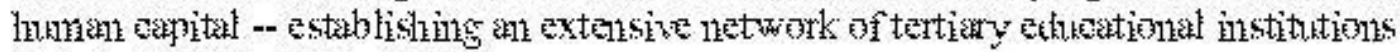
(Alestak 1993; Cribb 1994).

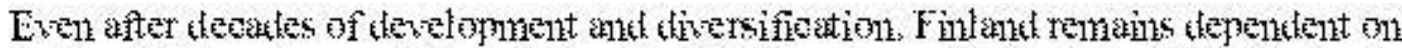
trake with its eastem neighbor. When the LSSR oollapsed in the late $1980 \mathrm{~s}$, Fintank

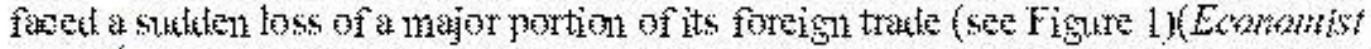

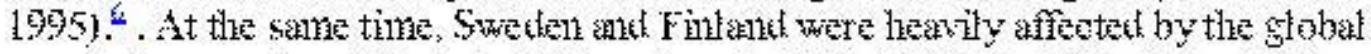
eennomie reession of the late 1980 s and early $1990 \mathrm{~s}$. With the highest levels of 1.1employment sine the Creat Deyression of the 1930 s (see Figne 2), both were fored

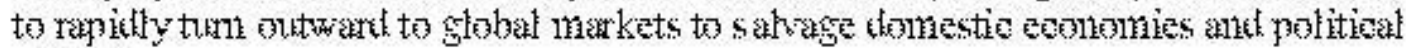
stability.

\section{Figure 1. Finland's exports to non-OECD countries, 1984-93}

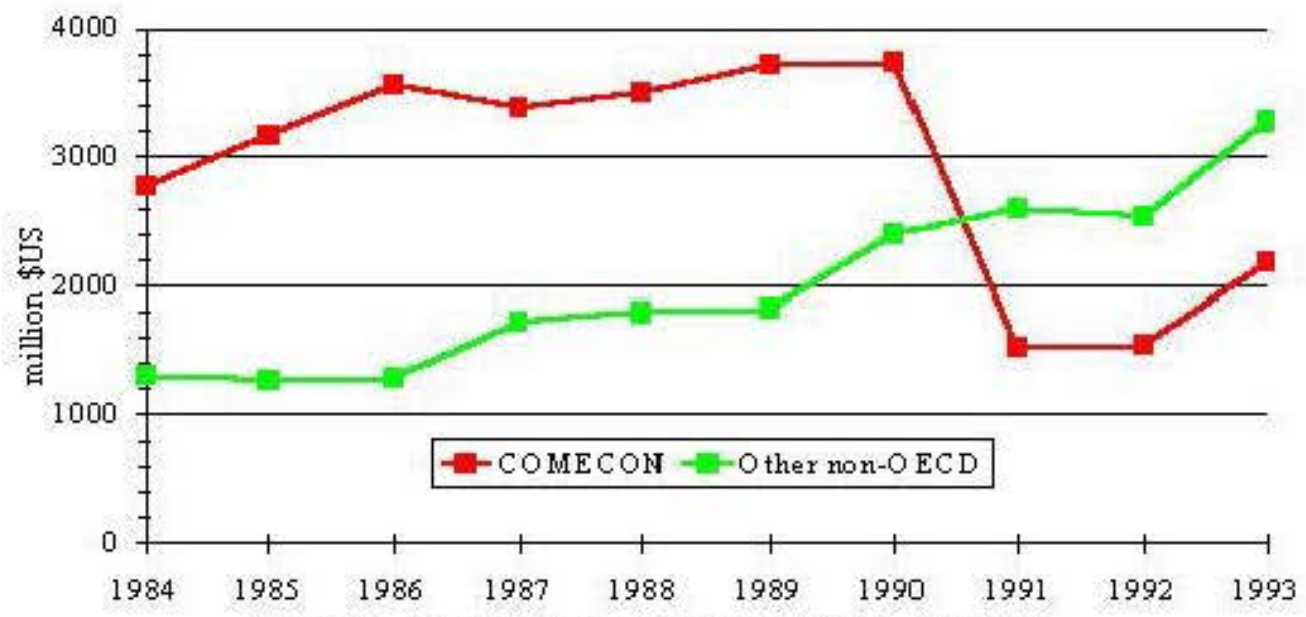

Figure 1. Fintant's non-OECD exports, $1984-93$. 


\section{Figure 2. Unemployment in Finland \& Sweden, 1981-95}

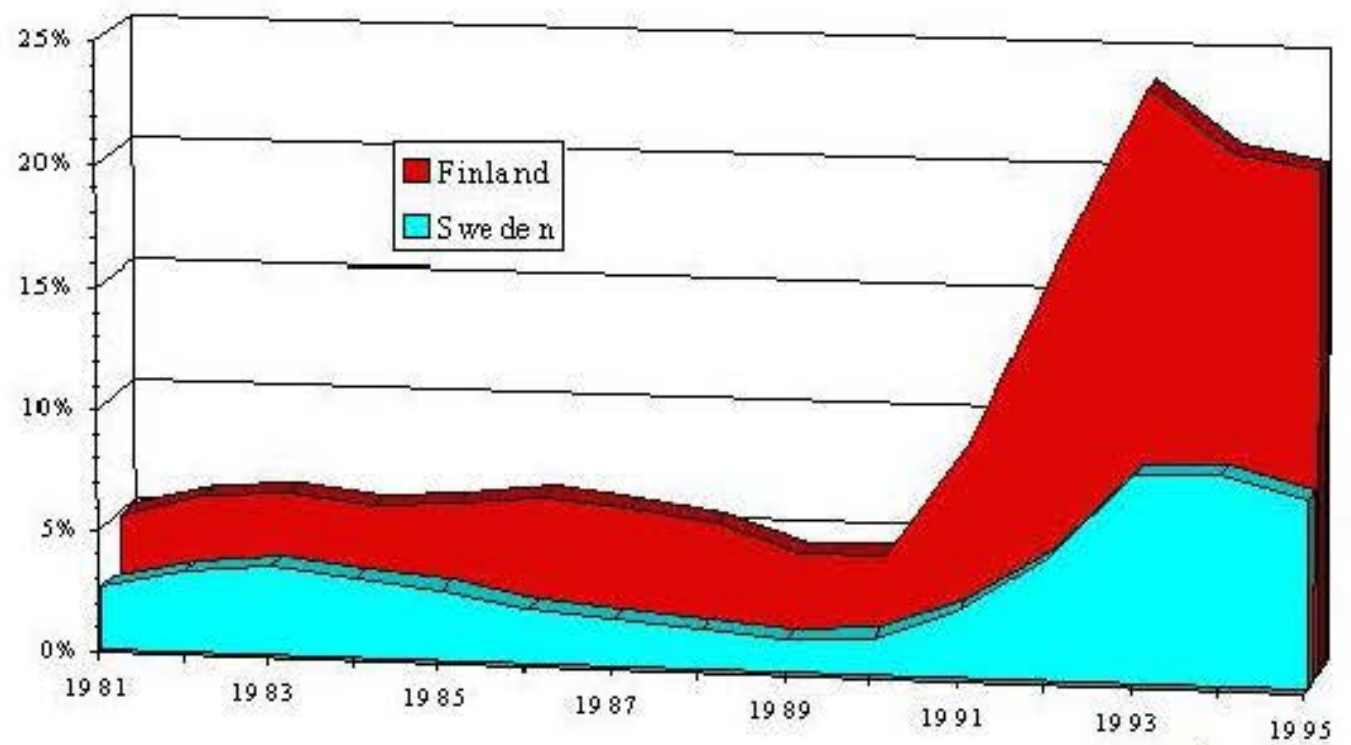

Figure 2. Finlatel's ant Sweten's themployment rates, $1981-98$ ?

[Prgge 29]

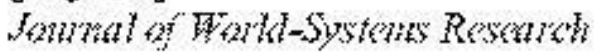

Soytheast A sia was among the few regions of the warlet boming in the late 1980 s and

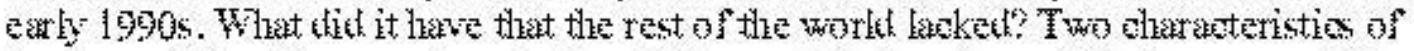

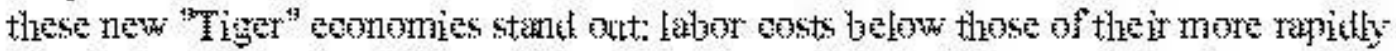

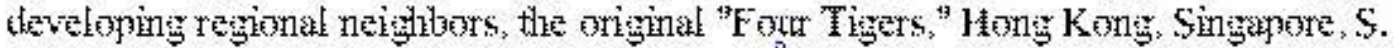

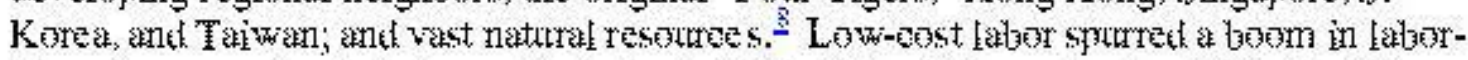

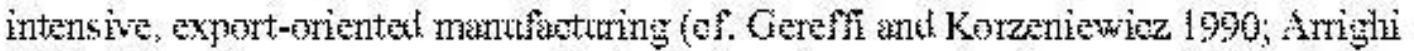
1996). Extensive resourees spurred a boom in primary protucetion -- agrientatural

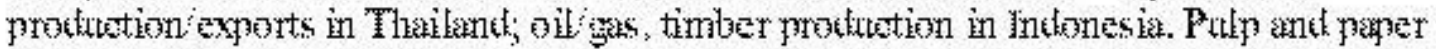
was one of the most rapikty expanthing indarstrial seetors in Sortheast Asia. This was for

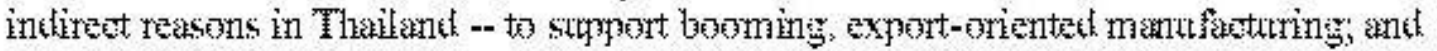
direet reasons in linkonesia --based on exploitation of that country's vast timber resoutres,

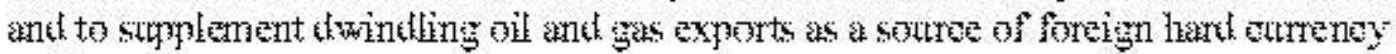
exchangenge.

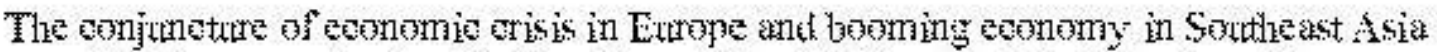
proviked strong motivation for Finnish and Swatish firms and states to strengthen exports to lndonesia, Thatkank, and elsewhere in Southeast Asia. In this they were quite 


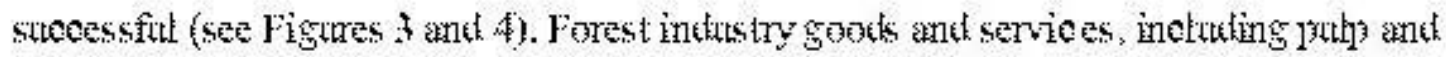
jotar tzelnologies, vere among the wargetzek exiorts.

Figure 3. Swedish exports to Southeast Asia, 1988-93

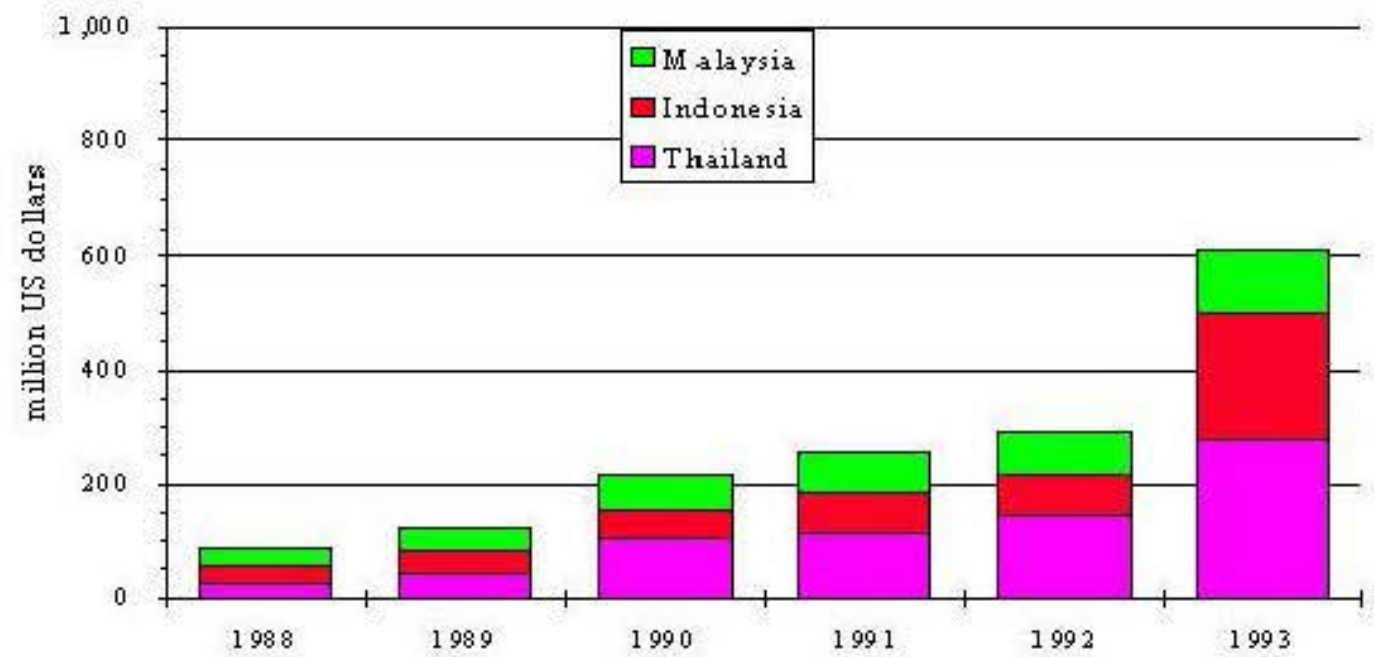

Figure 3. Sveden's exports to Southeast Asia, $1988-93$.

Figure 4. Finland's exports to Southeast Asia, 1988-93

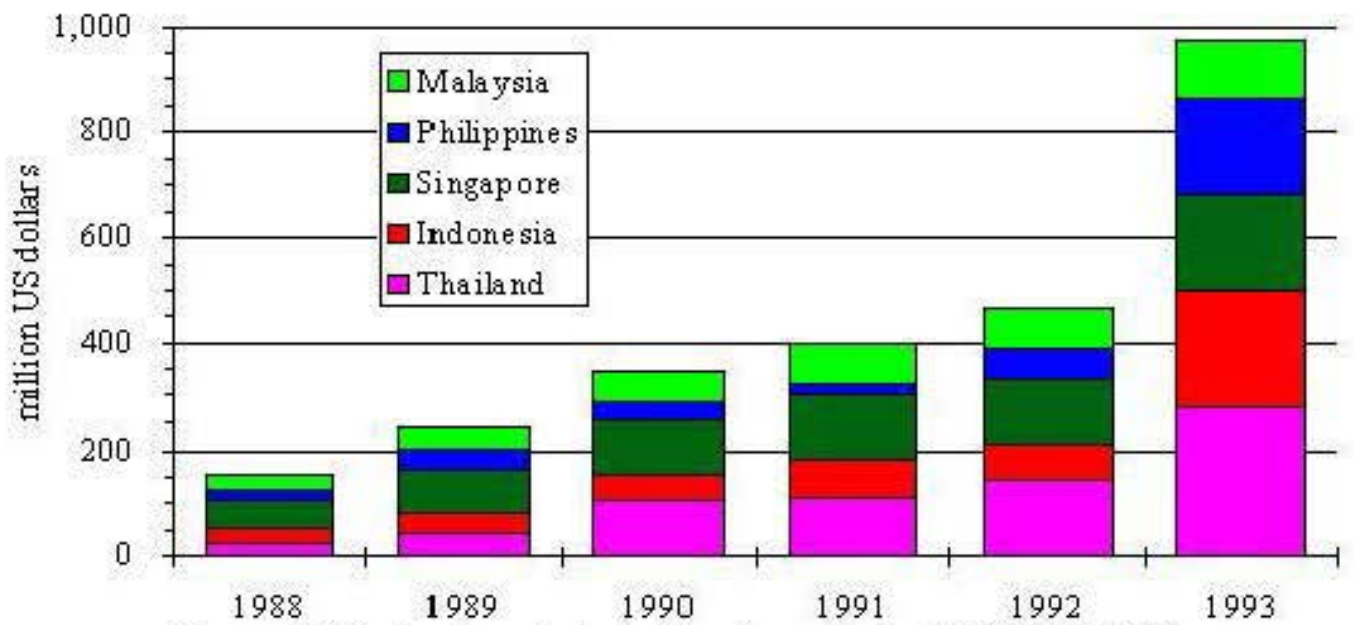

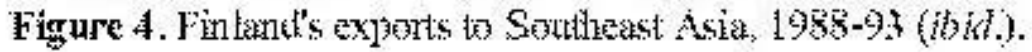


How was it that cleaner production technologies were among capital goods exported from the Nordic countries to Southeast Asia in the late 1980s and early 1990s? The technologies had been developed in Finland and Sweden in the 1980s in response to environmental protest. A return on the public and private investment in those new technologies was not immediately possible only in Europe, given the global economic recession and concomitant overcapacity in pulp and paper manufacturing. Meanwhile, along with its booming economy, Southeast Asia experienced dramatic expansion also of social protest and environmental activism, including in opposition to pulp industry pollution. Southeast Asian firms expanding at the time were incented to invest in the new, environmental technologies to help ensure the long-term security of their investments.

Following sections of this article analyze the history of Nordic "Vikings" involvement in development of Southeast Asia's forest industries; address local experiences and dynamics of the Southeast Asian new "Tigers"; and review some of the history of the development of the new technologies themselves. The article concludes with a discussion of the relevance of this case for theory of the world-system.

[Page 30]

Journal of World-Systems Research

\section{Vikings}

The groundwork for increasing Nordic economic involvement in Southeast Asia's forest sector was laid over at least a 30-year period. Jaakko Pöyry, a Finnish consulting engineering group, began work in Southeast Asia in the 1970s. In the late 1980s and early 1990s, Finnish and Swedish forest industry technology firms exported major amounts of capital goods to the region, aided by generous government grants, loans and credits. At the end of the century, Nordic firms and states have been taking advantage of global economic crises to establish world-dominant pulp and paper sector frames, including both manufacturing and technology. Moving from traveling, to trading, to taking substantial equity interests in and managing day-to-day operations of major Southeast Asian pulp and paper ventures, Nordic firms and states have progressively deepened their sectoral block with Southeast Asian firms.

\section{Travelers}

Jaakko Pöyry. Chief among early contemporary Nordic corporate travelers in Southeast Asia was the Jaakko Pöyry Co. The Jaakko Pöyry Group of consulting, contracting, and manufacturing companies based in Helsinki, Finland, founded by a pulp and paper engineer of the same name, has been of singular importance in the shaping of the forestrelated industries not only in Southeast Asia but also throughout the world (Hass 1978; Jaakko Pöyry 1993b; 1993c; Kerski 1995; Marchak 1995). 


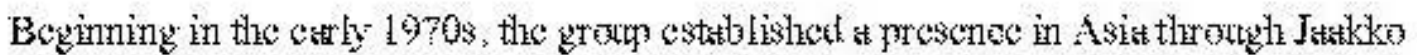
Poyy Consulting; with funting from the Asim Develogment Batnk (ADB) ant other

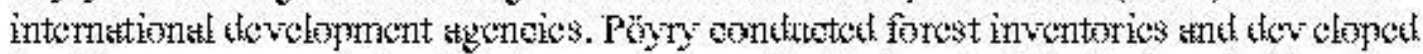

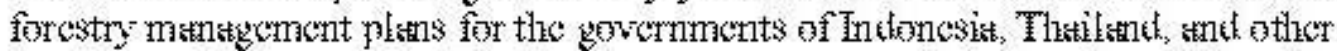

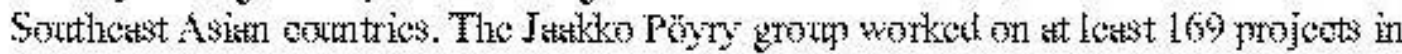

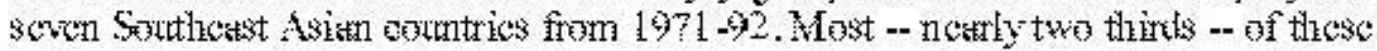

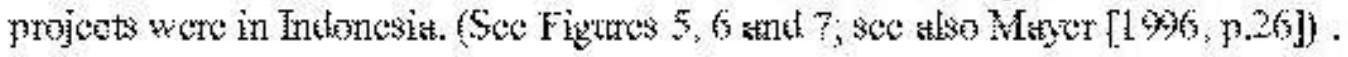

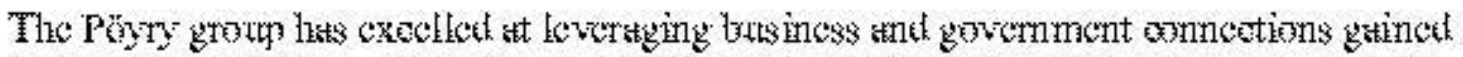

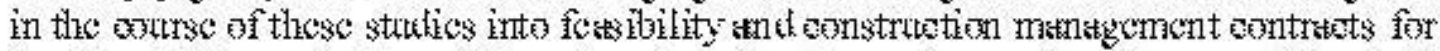

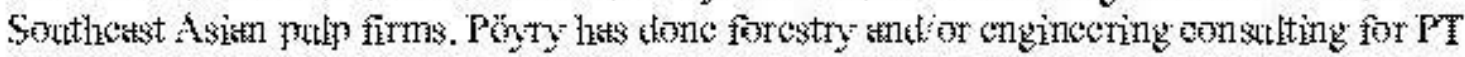

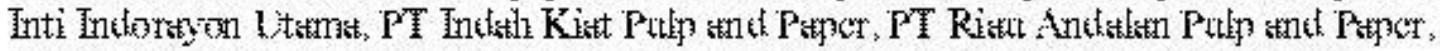

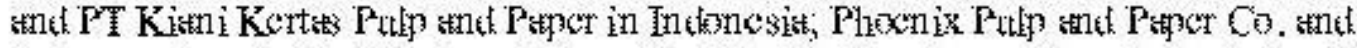

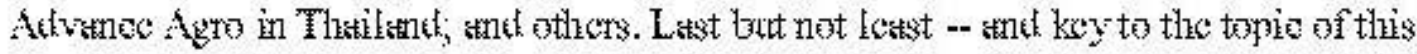

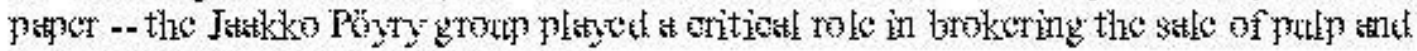
potser tednology in Sorthestst Askis.

Figure 5. Jaakko Pöyry Southeast Asian projects, $1971-92$

$$
(n=169)
$$

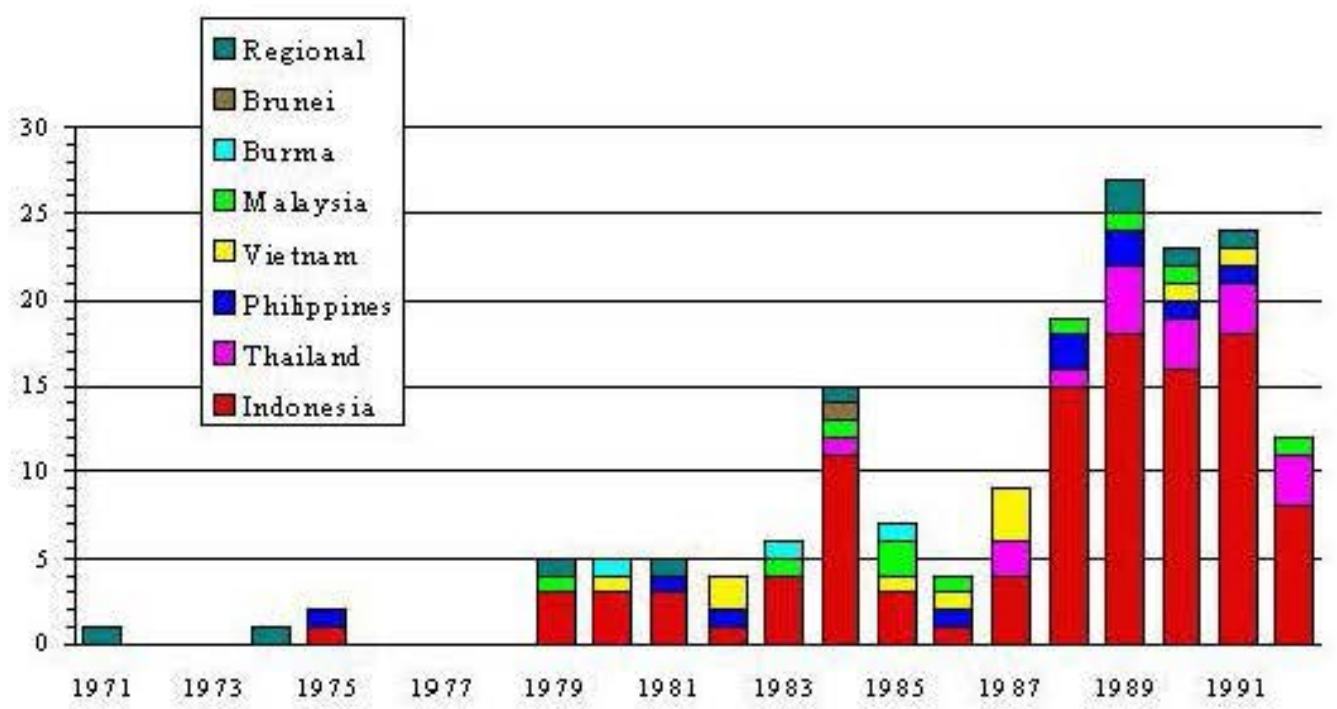

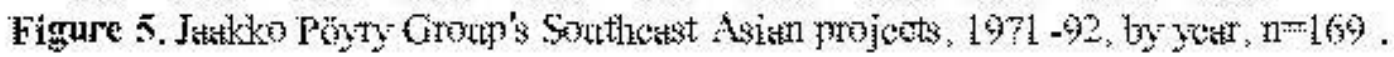




\section{Figure 6. Jaakko Pöyry Southeast Asian projects, 1971-92}

$$
(n=169)
$$

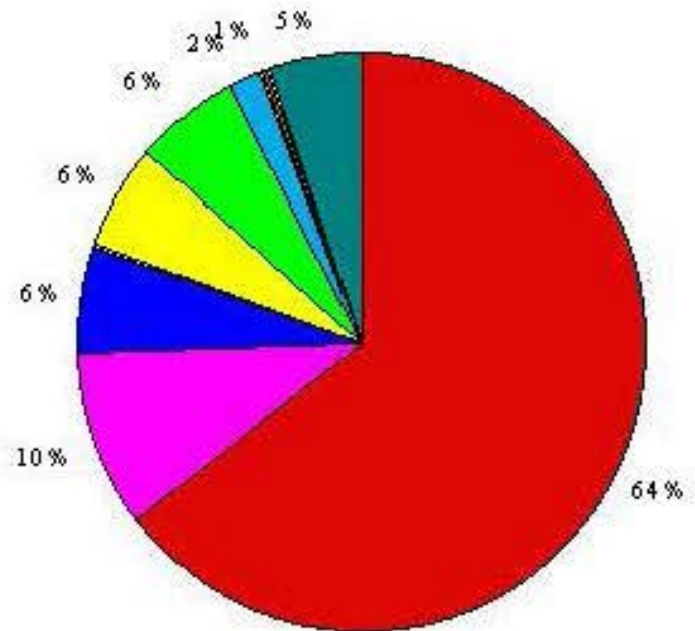

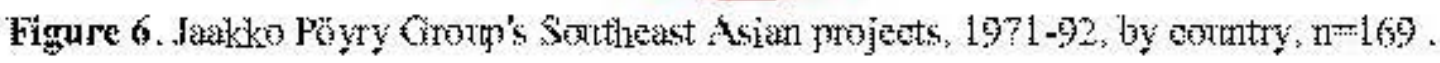

\section{Figure 7. Jaakko Pöyry group structure, c. 1993}

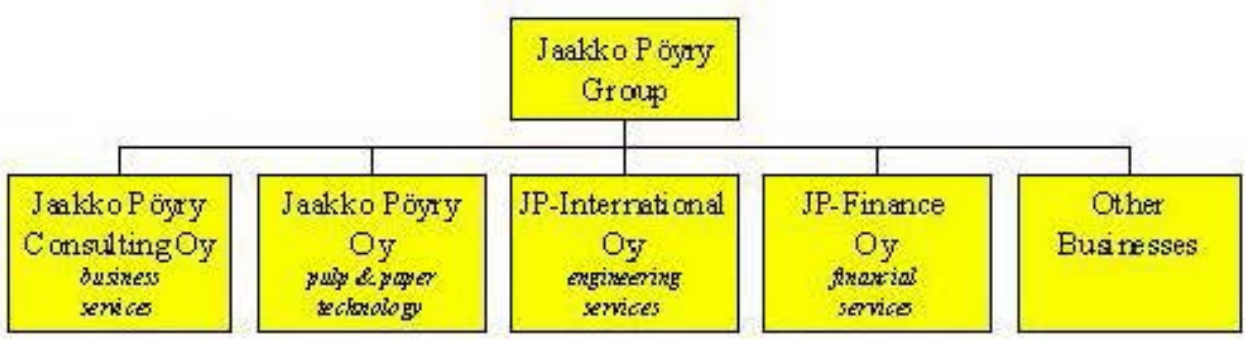

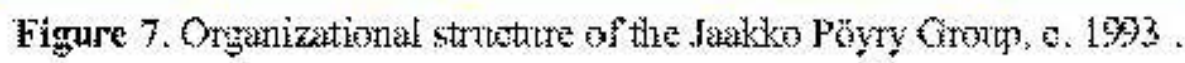

[Page 31]

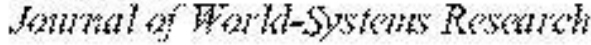

\section{Truklors}




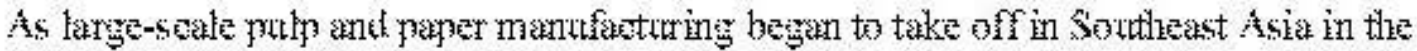
1.980s, several Norke firms were well-positionat to sell the dopital goods necessary to butilk that indastry. From the mik-1.980s throughl the mikl-1.990s, futping and bleseding tednolegy was provided by two Sweden-based firms: Strnds Defibrator, owned by the

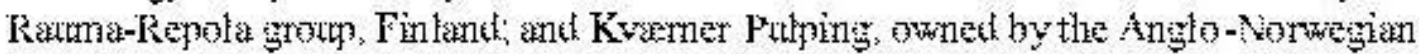

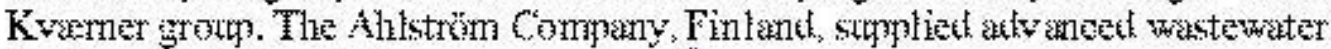
tratment and chemical reoovery systems.

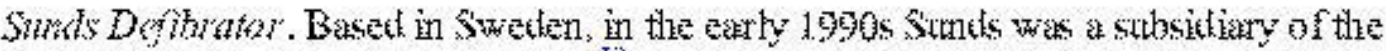

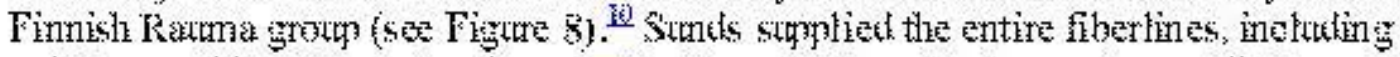

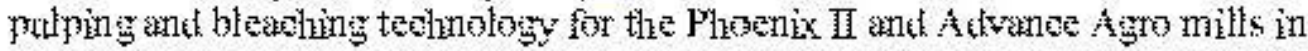

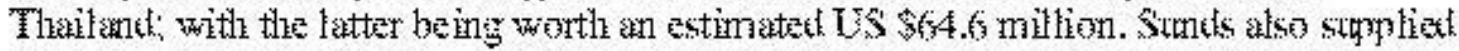

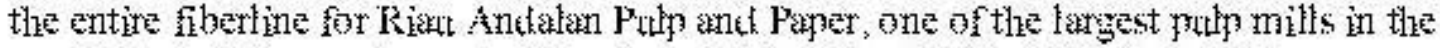

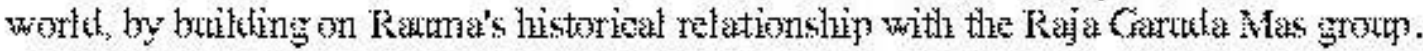

\section{Figure 8. Sunds Defibrator - Rauma Repola c. 1993}

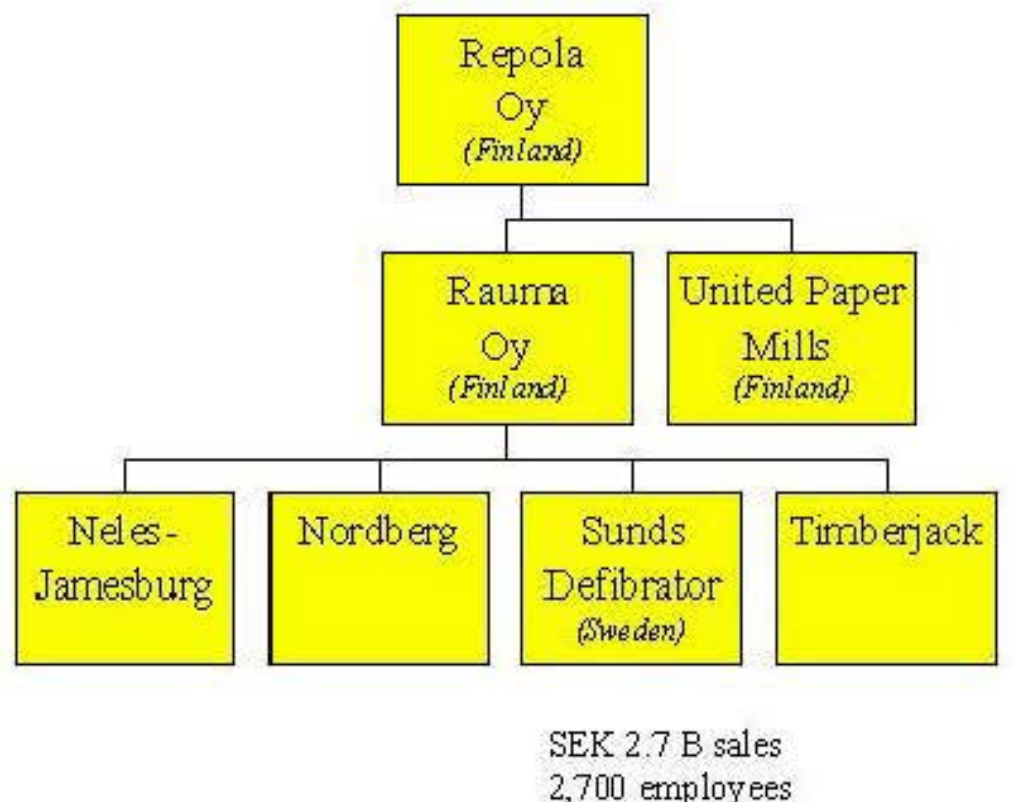

Figare 8. Stends Defilorator's pesition within the Rarana Repola grout? .

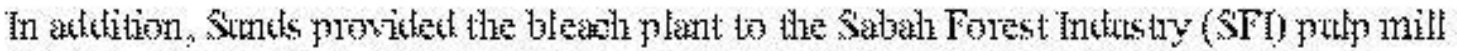

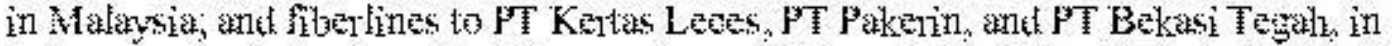

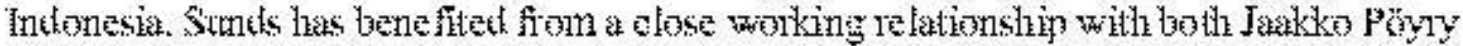

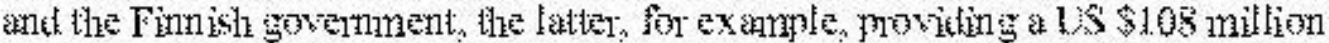

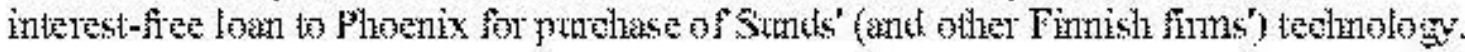

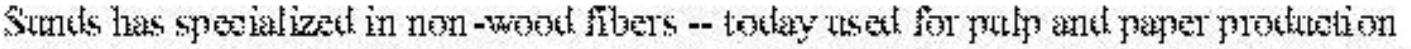

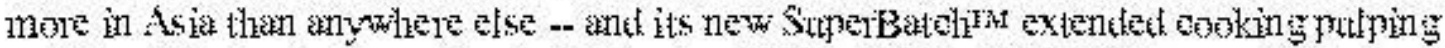

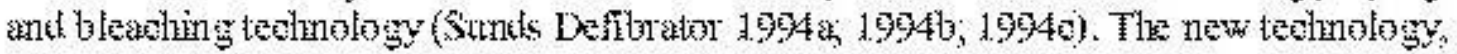


suited for use with more environmentally-friendly elementally chlorine-free (ECF) and totally chlorine-free (TCF) ${ }^{11}$ bleaching processes, was developed in the $1980 \mathrm{~s}$, building on work conducted by the Swedish Royal University of Technology and the Swedish Pulp and Paper Research Institute (STFI)(Lindstrom 1999). Sunds is also responsible, with the Union Camp Co., of Virginia, USA, for developing the C-Free ${ }^{\mathrm{TM}}$ TCF pulping and bleaching process (Sunds Defibrator 1993).

Kvorner Pulping. Kværner supplied pulping equipment to the Sabah Forest Industry (SFI) pulp mill in Malaysia, PT Indah Kiat Pulp and Paper's (IKPP) Mill \#2 in Indonesia; and Siam Cellulose in Thailand. More recently, and more importantly in terms of this article, Kværner supplied its new Iso-Thermal Cooking (ITC ${ }^{\text {TM}}$ ) continuous pulping technology with ECF bleaching to IKPP's Pulp Mill \#8 and PT Wira Karya Sakti, IKPP's sister company, also in Indonesia. Both became operational in 1994.

Kværner got its start in the pulp industry in the early 1970s, when it joined forces with the Ahlström Company, from Finland (see below), and Myrens Verksted a/s, a holding of the Axel Johnson group of Sweden, to form Kamyr $a / b$, one of the world's leading pulp technology firms. In 1989, the Johnson group sold its share to the two other partners. Ahlström obtained exclusive marketing rights for the North American market, while Kværner gained rights to use the Kamyr name everywhere else, including Southeast Asia. In 1993, Kværner and Ahlström dissolved their partnership and Kværner began using its own name.

[Page 32]

Journal of World-Systems Research

The Kværner group is based in Norway, with major units throughout the Nordic countries and elsewhere. In the early 1990s, pulp and paper was one of the company's five major business sectors, along with shipbuilding, shipping, manufacturing oil and gas platforms, and mechanical engineering. Kværner's Pulp and Paper Division employed about 1500 of the group's 23,000 employees (see Figure 9). $\stackrel{12}{ }$ 


\section{Figure 9. Kvarner group business areas c. 1993}

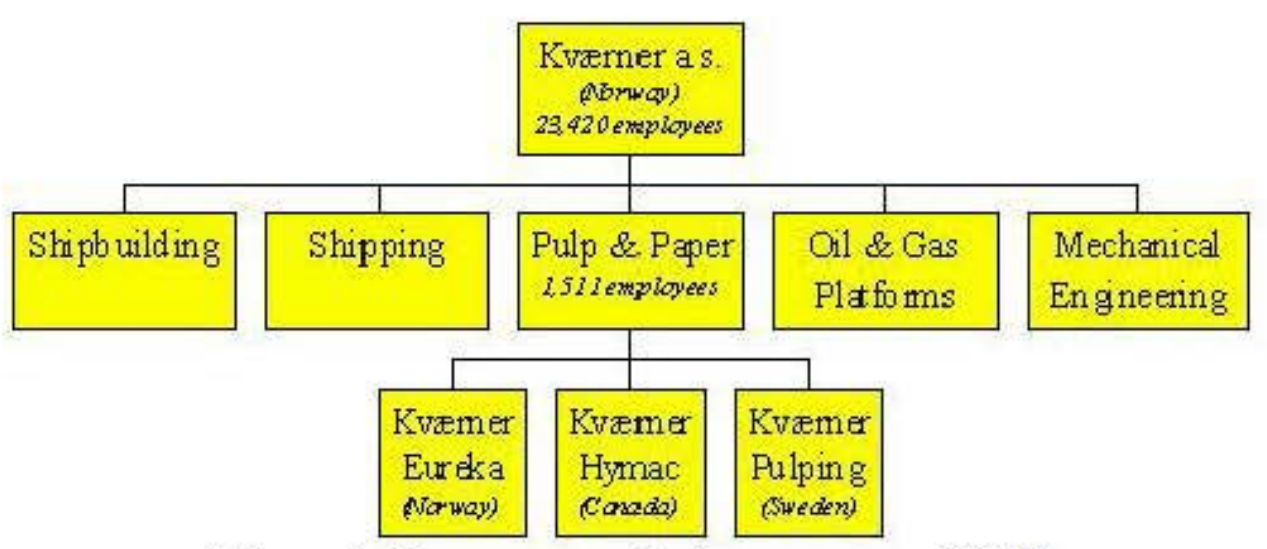

Figure 9. Kverner grow business areas, 0. 1994. iz

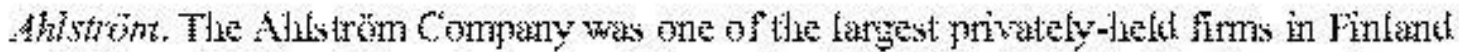
tentil the end of the 20t1 century. As of Dacember 31, 1994, Atlström family members

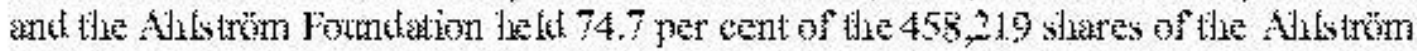

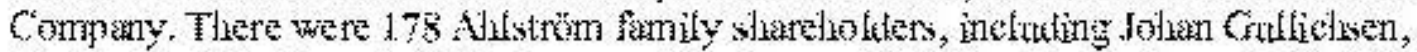
Chatrman of the Boand of Directors, and Professer of Pufping Tedunglogy at Helsinki

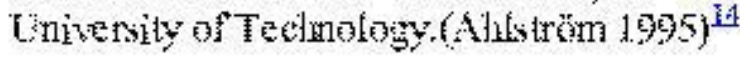

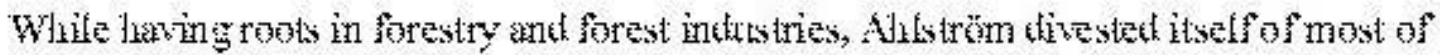

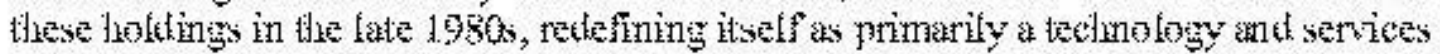
company (Ramolin 1.993. Aviström 1.994a). In the mikt-1.900s, Aulström describet itseff

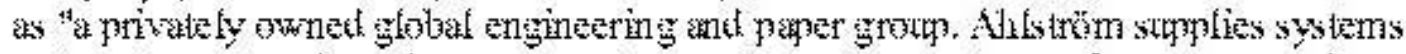

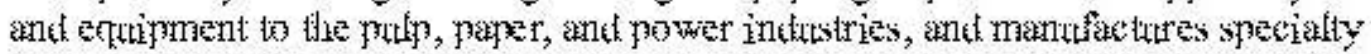
papers: (Avilistrom 1.995)

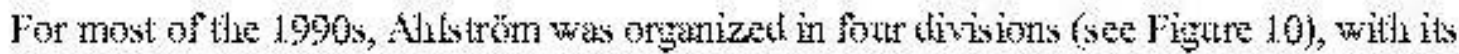

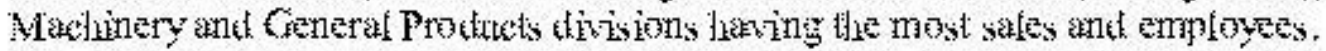

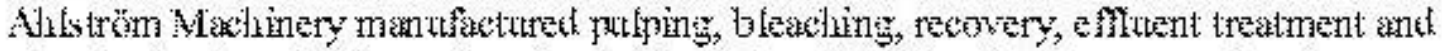

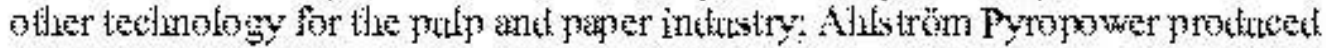

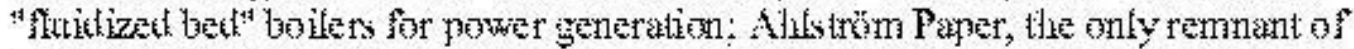

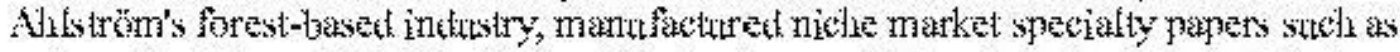

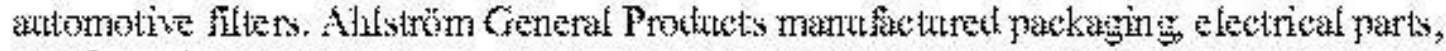
and fiverghtass.

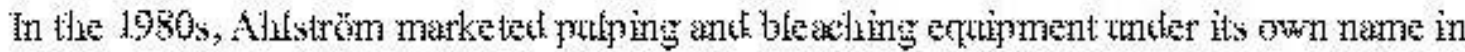
Enroge, and as Kamyr, Ine, in Nortil America, theder terms of the Kamyr partnersilis?

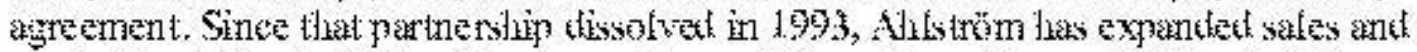

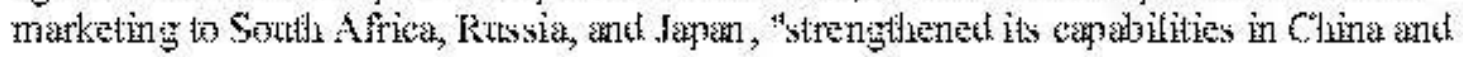


Intia and openet a new offee in Thailant" (Ahlströn $1991 ; 1992 ; 1993 ; 19946$; and $1995)$.

[Page 33]

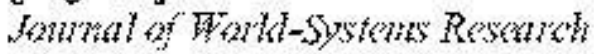

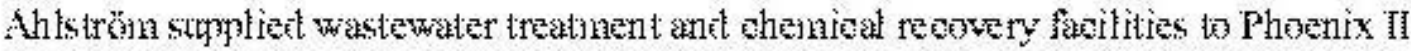

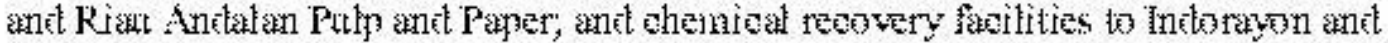

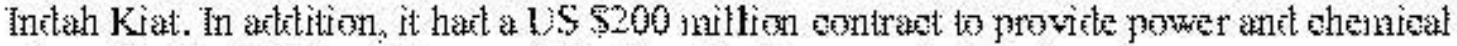
plants for the PT Kiani Keftas mill in East Katinantan. Intionesia.

\section{Figure 10. Ahtström Company divisions, c. 1993}

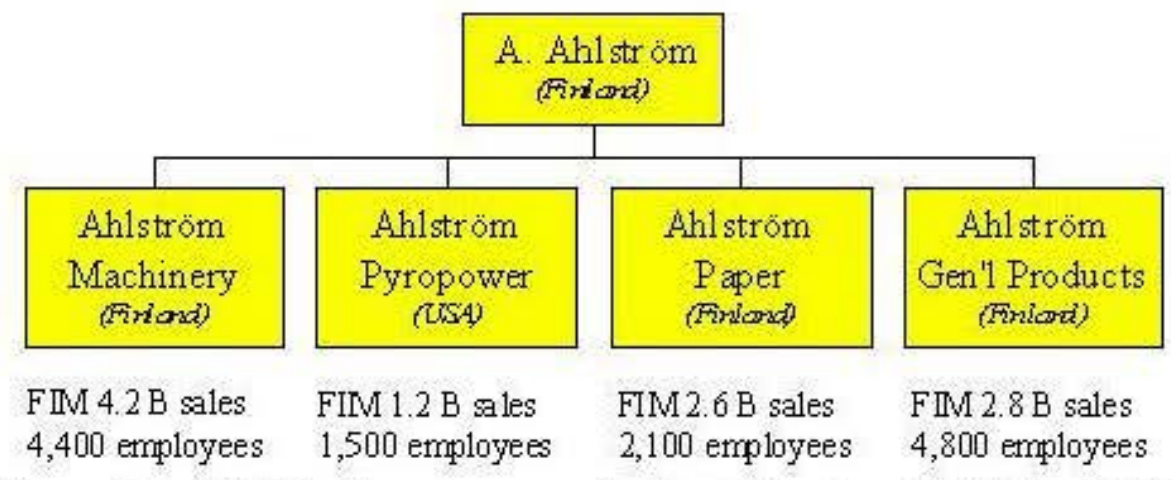

Figure 10. Allström Company organizational strutute (At1ström 1995)

\section{Tukdowors}

In the late 1990 , ilistindions ameng voritie tednology firms, and between these firms

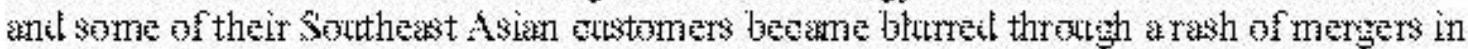

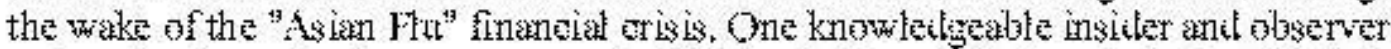

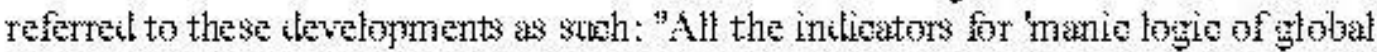
conitalism' (Greiler) are explieit here in axtr little partilise ... it's the raee within Finnish indutstry [to see] whe is quickest to make the next mowe (wilenines 1999 ).

EPA-Kymmow. The Kymmene and Rama-Repola oompan ies merged in late 199 ? to

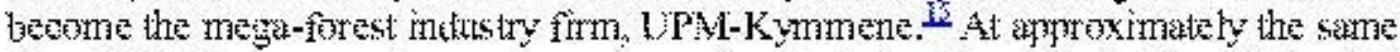

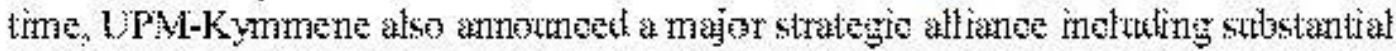
equaty holkings in a joint venture with the Singapore-based Asia Paeife Resoures holding groun (APRIL), onerators of PT Riar Andats Pulp and Pager and PT Inti 
Indorayon Utama, in Indonesia (UPM-Kymmene 1997). In 1998-99, UPM-Kymmene launched a joint venture with the Finnish state, principle shareholder of the Valmet Corporation, leading producer of papermaking machines, to form a new, combined technology powerhouse -- the Rauma-Valmet Corporation, including Sunds Defibrator (UPM-Kymmene 1998).

Stora Enso. UPM-Kymmene's mergers and acquisitions were in response to the earlier merger of two other Nordic forest sector powerhouses, the Swedish Stora company, and the Finnish state-owned Enso Oyj pulp and paper firm (Wilenius 1999; Stora Enso Oyj 1998). ${ }^{16}$ Like UPM-Kymmene, Stora Enso is poised to become a major player in Southeast Asian pulp and paper manufacturing. Enso is joint partner with the parastatal Inhutani III forestry corporation in Indonesia, together with the Gudang Garam group -manufacturers of clove cigarettes and one of Indonesia's largest consumer goods exporters (World Paper 1994a). The firms hope to construct a large-scale, exportoriented pulp mill in West Kalimantan, Indonesia, near several pulp plantations, including one of their own (World Paper 1994b; World Paper 1995). 17 Also, in 1998 Enso announced a strategic alliance with the Advance Agro Co., major integrated pulp and paper manufacturer, in Thailand (Nation 1998a; Enso Oyj 1998). Through Enso's mergers and alliances as well as the Valmet-Rauma (Sunds Defibrator) merger, the Finnish state and Nordic private capital have direct equity stakes in many aspects of global pulp and paper manufacturing, including in Southeast Asia.

Kvorner/Ahlström. Meanwhile, suffering heavily from the Asian flu (Kværner 1998b), in early 1999, the Kværner group was (re-)merging its Kværner Pulp and Paper division with Ahlström's Machinery division (Kværner 1998a; Virtual Finland 1998) -- shades of the old, failed Kamyr Corporation -- though under good terms this time (Wilenius 1999). Both the Kværner and Ahlstrom Companies had been hit hard by the Asian financial downturn and were engaged in major organizational restructuring.

[Page 34]

Journal of World-Systems Research

\section{... And Tigers}

Who were the Southeast Asian firms who in the last three decades sought help from Nordic corporate "travelers" in the expansion of pulp and paper manufacturing in the region, purchased capital goods including cleaner production technologies from Nordic "traders," and most recently have wooed and been wooed by Nordic public and private "take-over" interests? Key "Tiger" firms included the Phoenix Pulp and Paper Co. and Advance Agro Corporation, in Thailand; and PT Indah Kiat Pulp and Paper (IKPP) and PT Riau Andalan Pulp and Paper (RAPP) in Indonesia. 


\section{Phoenix}

Phoenix Pulp and Paper was the first company to bring an ECF bleached chemical pulp mill into commercial production in Southeast Asia, in July 1994. Phoenix began exploring adding a second pulp line at its facilities in northeast Thailand in the mid1980s. They hired Jaakko Pöyry to conduct a feasibility study for them. While planning the expansion, Phoenix came into conflict with local community residents concerning pollution from the company's existing pulp line (see Sonnenfeld 1998a). Phoenix upgraded its wastewater treatment facilities (using Ahlström equipment), but was nevertheless notified by government authorities that they would have to completely eliminate discharges into the neighboring Phong River (Nam Phong) within a few years.

In this context, Phoenix decided to "turn necessity into a virtue" and adopted an ambitious new corporate goal -- to become one of Asia's first "zero-discharge" pulp mills. To attempt to achieve this goal, Phoenix also added oxygen delig nification ${ }^{18}$ to its existing pulp line and initiated a program to use treated wastewater to irrigate eucalyptus plantations on nearby lands. Phoenix's new pulp line was planned to incorporate the latest pulping and bleaching technology to help meet this goal. Phoenix's expansion and environmental upgrading was underwritten by a US $\$ 108$ million interest-free loan from Finnish development authorities (Reuters News Service 1994b). Sunds Defibrator supplied an ECF SuperBatch ${ }^{\mathrm{TM}}$ fiberline ${ }^{19}$ for Phoenix's new mill. ${ }^{20}$

At the time of my site visit in August 1994, officials hoped that Phoenix's facilities would be clean enough to merit eco-certification for its products. If obtained, eco-certification would position Phoenix as a low-cost "environmental pulp" producer, since a substantial portion of its pulp is from non-wood (bamboo and kenaf) sources. Such a position could command premium prices in countries with "green" consumer markets -- in the mid1990 s, Phoenix claimed to be obtaining high prices in Japan for its kenaf pulp for use in "wood-free" paper products..$^{21}$

\section{Advance Agro}

Advance Agro is one of Thailand's newest pulp and paper mills. It was built in the northeastern region of the country by the Soon Hua Seng (SHS) group, one of Thailand's largest integrated agro-industrial business groups. SHS was mired in controversy in the 1980s for the role of a subsidiary, Suan Kitti, in cutting natural forests to establish eucalyptus plantations (see Sonnenfeld 1998a). Originally planned as the "Suan Kitti Pulp Mill," the mill's name was changed to insulate it from public and political pressure. Jaakko Pöyry and H.A. Simons, a Canadian firm, were hired as technical consultants for the mill.

SHS, wanting to minimize the impact of the Suan Kitti controversy on government approval of its proposed pulp and paper complex, hired the Finnish-owned and Bangkokbased, Presko public relations firm for advice on environmental matters. Sunds Defibrator provided ECF pulping and bleaching equipment for the mill, which began 
operations in 1996. In 1998, Advance Agro formed a "strategic alliance" with the Finnish Enso Company and Japanese Oji Paper Co.(Nation 199b).

\section{Indah Kiat}

The Sinar Mas Group, a diversified, integrated agro-industrial, real estate and financial group of companies based in Jakarta, began producing pulp at its IKPP mill in Riau, in 1984, using imported second-hand equipment from one of its Taiwanese joint venture partners. With substantial production and demand already for its various lines of bleached paper products, IKPP added a second pulp line (its first new pulp mill) in 1990, using Kamyr pulping equipment.

IKPP and its sister companies were so wildly successful that, with a downturn in the world's pulp and paper industry in the 1990s, the group seized on an opportunity to purchase new pulp and paper technology at "rock bottom" prices. Two new large pulp lines were built, one (Pulp Mill \#8) at IKPP at Perawang, and one at PT Wira Karya Sakti, a sister mill in Jambi province, also on the island of Sumatra. Both are in operation today with Kværner's ITC ${ }^{\text {TM }}$ ECF pulping and bleaching technologies. Jaakko Pöyry has worked closely with IKPP over the years both in the company's plantation forestry program and as technical advisor. Funding for the new mills came at least in part from the international corporate bond market.

In 1995, the Sinar Mas Group "spun off" its pulp and paper interests to Singapore-based Asia Pulp \& Paper Co. Ltd. (APP). Shortly thereafter, APP successfully floated millions of dollars of corporate bonds on the international markets, including in the USA, for expanded paper production in India and China. In 1998, APP announced plans to participate in a joint venture in a pulp mill in the Malaysian Borneo state of Sarawak . Also in 1998, APP announced a "global strategic alliance" with the Japanese Itochu corporation (APP 199b). As of the writing of this article, reports suggested that APP had over US $\$ 3$ billion in debts on international capital markets (Reuters News Service 1999).

[Page 35]

Journal of World-Systems Research

\section{Riau Andalan}

The Raja Garuda Mas (RGM) group, headed by the Tanoto family, among Indonesia's foremost plywood industry entrepreneurs, got into pulp production in North Sumatra in 1988 at their PT Inti Indorayon Utama (PT IIU) cellulose mill. They reportedly used second-hand equipment for the mill from Finland, including pulping and bleaching equipment from Rauma Repola, imported via a Taiwanese equipment company the Tanoto's had an interest in. 
Despite a rocky history of engineering and political problems at the PT IIU mill (see Sonnenfeld 199b), RGM planned what today is one of Indonesia's newest, and one of the world's largest pulp mills, in Riau, operating as RAPP. RGM hired Jaakko Pöyry to conduct a feasibility study and act as design consultant for the mill. Riau Andalan Pulp and Paper's entire fiberline, including ECF pulping and bleaching equipment, was provided by Sunds Defibrator. Funding for the project came at least in part from the international corporate bond market.

In 1995, like its competitors, the Raja Garuda Mas group spun off its pulp and paper companies to a separate, Singapore-based holding company, Asia Pacific Resources International Holdings Ltd. (APRIL). Like APP, APRIL also sold corporate bonds on international capital markets to raise funds for continued expansion. In 1997, UPMKymmene initiated a strategic alliance with APRIL, taking partial ownership of various APRIL facilities. (One of UPM-Kymmene's subsidiaries, Sunds Defibrator, had supplied pulping equipment to the RAPP mill.) In early 1999, APRIL spun off PT IIU, due to continued conflict surrounding that operation (APRIL, 1999).

\section{Summary}

Results of three decades of Nordic involvement in the industrialization of Southeast Asia's forest sector are summarized in Table 1, below. From 1981 through 1996, almost all bleached kraft pulp mills built in Southeast Asia used Nordic pulping and bleaching technology (see column 5, "pulping technology supplier"). 1992-94 were watershed years for adoption of the more advanced ECF pulping and bleaching technology in Southeast Asia (see column 6, "bleaching sequence"). ${ }^{22}$ Jaakko Pöyry served as contracting engineer for approximately two-thirds of those ventures (see column 7 , "contracting engineer"). The five bleached chemical pulp mills which commenced production in Southeast Asia from 1994-96, all use technology designed to produce ECF pulp, and to be adaptable to producing TCF pulp as demanded by global and domestic pulp and paper markets.

Table 1

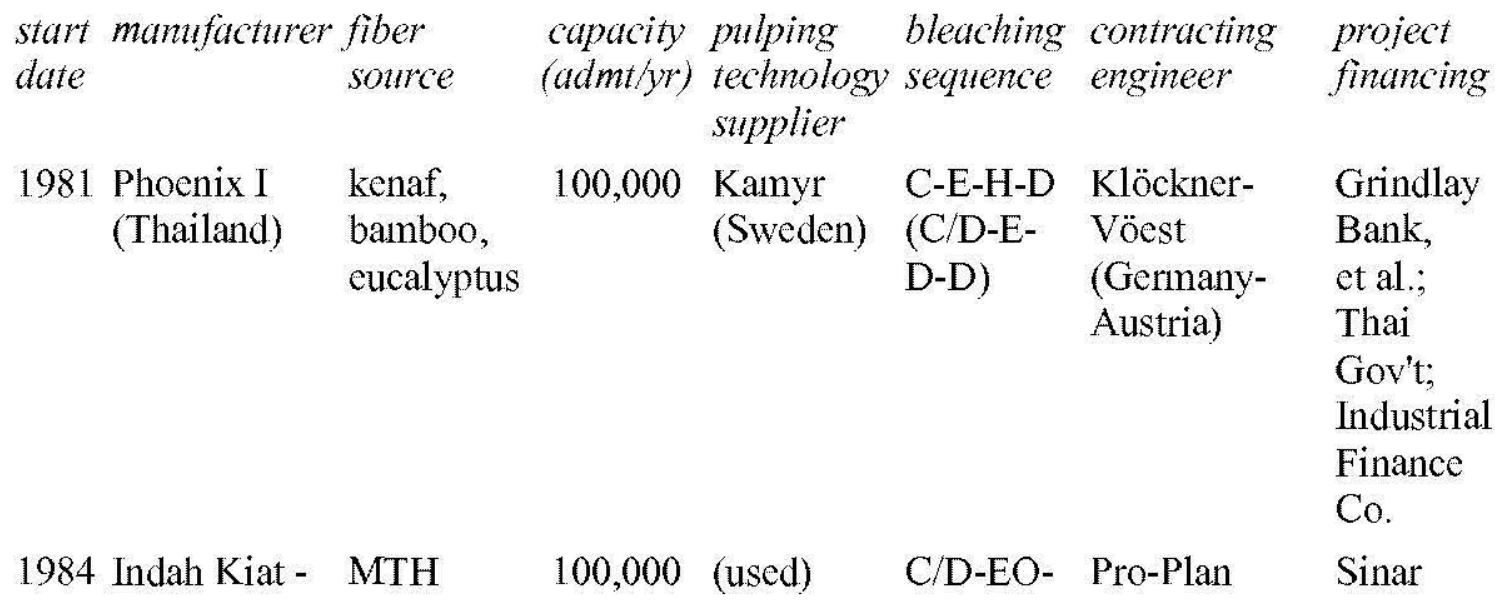




\begin{tabular}{|c|c|c|c|c|c|c|c|}
\hline & $\begin{array}{l}\text { Pulp Mill \#1 } \\
\text { (Indonesia) }\end{array}$ & & $(120,000)$ & & H-D-E-D & (Austria) & $\begin{array}{l}\text { Mas; } \\
\text { Yuen } \\
\text { Foong } \\
\text { Yu; } \\
\text { Chung } \\
\text { Hwa }\end{array}$ \\
\hline 1987 & $\begin{array}{l}\text { Sabah Forest } \\
\text { Industries } \\
\text { (Malaysia) }\end{array}$ & MTH & 100,000 & Kamyr & $\begin{array}{l}\mathrm{C} / \mathrm{D}-\mathrm{EO}- \\
\mathrm{D} \\
\text { (D/C-EO- } \\
\mathrm{D}-\mathrm{D})\end{array}$ & $\begin{array}{l}\text { Klöckner- } \\
\text { Vöest }\end{array}$ & $\begin{array}{l}\text { State of } \\
\text { Sabah; } \\
\text { gov't } \\
\text { loans } \\
\text { from } \\
\text { Canada, } \\
\text { Austria \& } \\
\text { Germany }\end{array}$ \\
\hline 1988 & $\begin{array}{l}\text { Inti } \\
\text { Indorayon } \\
\text { Utama } \\
\text { (Indonesia) }\end{array}$ & pine & $\begin{array}{c}180,000 \\
(240,000)\end{array}$ & $\begin{array}{l}\text { Rauma } \\
\text { Repola } \\
\text { (Finland) }\end{array}$ & $\begin{array}{l}\text { C/D-EO- } \\
\text { H-D }\end{array}$ & $\begin{array}{l}\text { Sandwell } \\
\text { (Canada)/ } \\
\text { Jaakko Pöyry } \\
\text { (Finland) }\end{array}$ & $\begin{array}{l}\text { Gov't } \\
\text { bank } \\
\text { loans }\end{array}$ \\
\hline 1990 & $\begin{array}{l}\text { Indah Kiat - } \\
\text { Pulp Mill \#2 }\end{array}$ & MTH & $\begin{array}{c}180,000 \\
(380,000)\end{array}$ & $\begin{array}{l}\text { Sunds } \\
\text { Defibrator } \\
\text { (Sweden) }\end{array}$ & $\begin{array}{l}\text { C/D-EO- } \\
\text { D }\end{array}$ & Jaakko Pöyry & $\begin{array}{l}\text { Sinar } \\
\text { Mas; } \\
\text { Yuen } \\
\text { Foong } \\
\text { Yu; } \\
\text { Chung } \\
\text { Hwa; } \\
\text { public } \\
\text { stock } \\
\text { offering } \\
\text { (Jakarta) }\end{array}$ \\
\hline 1992 & $\begin{array}{l}\text { Siam } \\
\text { Cellulose } \\
\text { (Thailand) }\end{array}$ & $\begin{array}{l}\text { bamboo, } \\
\text { eucalyptus }\end{array}$ & 50,000 & Kamyr & C-EOP-H & $\begin{array}{l}\text { Klöckner- } \\
\text { Vöest }\end{array}$ & $\begin{array}{l}\text { Siam } \\
\text { Cement }\end{array}$ \\
\hline 1994 & Phoenix II & eucalyptus & 100,000 & $\begin{array}{l}\text { Sunds } \\
\text { Defibrator }\end{array}$ & $\begin{array}{l}\text { D-EO-D- } \\
\text { D }\end{array}$ & Jaakko Pöyry & $\begin{array}{l}\text { Finnish } \\
\text { Export } \\
\text { Credit } \\
\text { Ltd. }\end{array}$ \\
\hline 1994 & $\begin{array}{l}\text { Indah Kiat - } \\
\text { Pulp Mill \#8 }\end{array}$ & MTH & 380,000 & $\begin{array}{l}\text { Kværner } \\
\text { Pulping } \\
\text { (Sweden) }\end{array}$ & $\begin{array}{l}\text { D/C- } \\
\text { EOP-D-D }\end{array}$ & Jaakko Pöyry & $\begin{array}{l}\text { corporate } \\
\text { bonds }\end{array}$ \\
\hline 1994 & $\begin{array}{l}\text { Wira Karya } \\
\text { Sakti } \\
\text { (Indonesia) }\end{array}$ & MTH & 380,000 & $\begin{array}{l}\text { Kvarner } \\
\text { Pulping }\end{array}$ & $\begin{array}{l}\mathrm{D} / \mathrm{C}- \\
\text { EOP-D-D }\end{array}$ & Jaakko Pöyry & $\begin{array}{l}\text { corporate } \\
\text { bonds }\end{array}$ \\
\hline 1995 & $\begin{array}{l}\text { Riau } \\
\text { Andalan }\end{array}$ & MTH & 750,000 & $\begin{array}{l}\text { Sunds } \\
\text { Defibrator }\end{array}$ & $\begin{array}{l}\text { D-EO-D- } \\
\text { D }\end{array}$ & Jaakko Pöyry & $\begin{array}{l}\text { corporate } \\
\text { bonds }\end{array}$ \\
\hline
\end{tabular}


(Indonesia)

\begin{tabular}{|c|c|c|c|c|c|c|c|}
\hline 1996 & $\begin{array}{l}\text { Advance } \\
\text { Agro } \\
\text { (Thailand) }\end{array}$ & eucalyptus & 175,000 & $\begin{array}{l}\text { Sunds } \\
\text { Defibrator }\end{array}$ & $\begin{array}{l}\text { D-EO-D- } \\
\text { D }\end{array}$ & $\begin{array}{l}\text { Jaakko } \\
\text { Pöyry/ } \\
\text { HA Simons } \\
\text { (Canada) }\end{array}$ & $\begin{array}{l}\text { Bangkok } \\
\text { Bank, } \\
\text { Thai } \\
\text { Farmers } \\
\text { Bank, } \\
\text { Krung } \\
\text { Thai } \\
\text { Bank, } \\
\text { Common- } \\
\text { wealth } \\
\text { Develop. } \\
\text { Corp. } \\
\text { (UK) }\end{array}$ \\
\hline 1996 & $\begin{array}{l}\text { Kiani Kertas } \\
\text { (Indonesia) }\end{array}$ & МTH & 472,000 & $\begin{array}{l}\text { Beloit/ } \\
\text { IMPCO }\end{array}$ & $\begin{array}{l}\text { "four- } \\
\text { stage" }\end{array}$ & Pöyry/Simons & $\begin{array}{l}\text { Finnish } \\
\text { Export } \\
\text { Credit, } \\
\text { Ltd. +? }\end{array}$ \\
\hline
\end{tabular}

Table 1. Technology employed in bleached chemical pulp production in Indonesia, Malaysia, and Thailand, $1981-97$ (various sources). ${ }^{23}$

[Page 36]

Journal of World-Systems Research

\section{Technology innovation}

Where had the new technologies come from? In the 1970s and '80s, Sweden and Finland experienced rising environmental movements and concerns, including those focused on pulp and paper manufacturing (Hellstrom and Reunala 1995; Raumolin 1992). Nordic pulp producers -- many of them state-owned -- were forced to meet increasingly restrictive environmental standards -- now among the toughest in the world. Sunds and Kamyr, in cooperation with university research institutes, launched research and development programs to modify existing technologies and develop new ones to meet the new standards (Nasman and Lindstrom 1994). By the end of the 1980s, these programs were bearing fruit, with Sunds' SuperBatch ${ }^{\mathrm{TM}}$ technology being launched in 1988, and Kværner's ITC'M technology and Ahlström's ozone bleaching systems in 1992 (Sunds Defibrator 1994c; Kvaerner Pulping 1994; Ahlström 1993). In taking a process reengineering approach to meeting environmental requirements, these firms traveled a different road than their North American counterparts who focused on developing new end-of-pipe technologies. 
These factors came together in the early 1990 s, resulting in the availability of Nordic environmental pulping and bleaching technology, urgent needs for new markets, and creative financing. Fortunately for the technology firms, this coincided well with the needs of Southeast Asia's new "Tigers." Jaakko Pöyry's forestry/forest industry consulting work provided important contacts and experience (Hass 1978; Jaakko Pöyry 1993g; Ulvila 1994a; Wallgren 1995). The history of local environmental conflicts around expansion of the industry, restrictive environmental regulations, and growing green international markets, provided additional reasons for the adoption of environmentally-friendly technologies in Southeast Asia's pulp sector.

The technologies utilized in these mills are world-class. This is in part a result of local community, environmental, and regulatory pressures. Nordic firms and governments have become major agents of transformation in Southeast Asia, however, by providing these technologies as well as the engineering, project management, and financing for many of these projects.

The long-term trend in the pulp technology worldwide is away from elementally chlorine $\left(\mathrm{Cl}_{2}\right)$ based, to $\mathrm{ECF}\left(\mathrm{ClO}_{2}\right)$, to closed-process (Edstrom 1994). How fast the industry moves in any one region depends on a variety of factors, some of which have been touched on in this paper, including the availability of technology, its price, general world economic conditions, local community conflict, national environmental regulations, $\stackrel{24}{ }$ the pull of green consumer markets, etc. The five bleached chemical pulp mills built in Southeast Asia in the mid-1990s had many of these factors working in their favor.

Social activism will continue to influence how much environmental technology gets adopted, however, and how it is used. Without continuing pressures from outside forces - government oversight, community pressure, consumer demand -- paper producers will likely optimize their mix of bleaching chemicals to suit their economic needs and product requirements. Thus for example, while Indah Kiat's Pulp Mill \#8 has ECF-capable technology, the company has run their new line with a chlorine dioxide-elemental chlorine (D/C) mix (Meadows 1995).

[Page 37]

Journal of World-Systems Research

\section{Conclusion}

What are the implications of the dynamics analyzed above for world-systems theory? First of all, the parallel rise of prominence of Nordic pulp technology firms and development of Southeast Asia's pulp and paper industries illustrates the consolidation of sectorally specific relations -- first cooperative, then increasingly exploitative -- between core firms and states and their peripheral counterparts, in the context of an evolving "new 
international division of labor," including peripheral industrialization. This is consistent with world-systems analysis of the development of semiperipheral and weaker ("peripheral-") core states into full core status (Arrighi and Drangel 1986), and of the tendency towards increasing polarization between core and periphery. Indonesia and Thailand show limited characteristics of semi-peripheralness in the forest industry/pulp and paper sector, especially since the "Asian Flu" financial crisis of 1997. Core-periphery relations have become increasingly po larized in the wake of the crisis, as a result of accelerated mergers, acquisitions and strategic alliances in the forest industry and related technology sectors globally, including in Southeast Asia.

The sale of capital goods associated with peripheral industrialization -- including now cleaner production technologies -- has multi-dimensional effects. Contrary to the conventional wisdom of the "pollution haven" hypothesis, in at least some sectors transnational firms, including technology firms, may actually be leading modernization of industry in newly industrializing countries. This suggests a further "advantage of backwardness" (Gershenkron 1966, cited in Chase-Dunn and Hall 1997, ch. 5) -- the ability to industrialize using cleaner production technology.

While arguably "cleaning up" manufacturing in Southeast Asia, sale of capital goods is a stepping stone in the increased domination of core over peripheral firms, states, and economies. This is in accordance with Arrighi's contention that:

...the industrialization of the ... periphery has ultimately been a channel, not of subversion, but of reproduction of the hierarchy of the world economy...

The relevant distinction is between activities that involve strategic decision making, control and administration, $R \& D$, on the one hand, and activities of pure execution, on the other. The core zone tends to become the locus of the "brain" activities of corporate capital, the peripheral zone tends to become the locus of the "muscle and nerves" activities ...(Arrighi and Drangel 1986, pp. 56-57) .

as well as Chase-Dunn's and Hall's argument that

upward mobility and transformational action are not necessarily the same thing. It is possible to succeed within a system without transforming the rules of that system. And it is possible to change the logic of social action without moving toward a more powerful or central location in a system (Chase-Dunn and Hall 1997, ch. 5).

Lastly, this case highlights capabilities and limitations of independent social movements across the world-system. As in Logan's and Molotch's (1987) work on the political economy of place and urban growth machines in the USA, social movements have largely not been able so much to affect the ultimate outcomes of economic development, but rather more to shape conditions under which that development takes place. In recent decades, social movements been more able to influence the nature but not fact of growth, development, and industrialization. In the present case, social movement activism has led 
to the relative greening of technologies employed in Southeast Asia's pulp and paper sector, while core-periphery relations have become increasingly polarized in the course of large-scale industrialization of the periphery.

[Page 38]

Journal of World-Systems Research

\section{Notes}

1. Presented at the Center for Western European Studies colloquium series, University of California, Berkeley, April 15, 1999, and an earlier version at the annual meeting of the Pacific Sociological Association, Seattle, Washington, March 21-24, 1996. This article was completed while the author was Ciriacy-Wantrup Visiting Scholar at the Institute of International Studies, University of California, Berkeley. Mr. Marko Ulvila, Tampere University, and Professor Judith Mayer, Virginia Polytechnic Institute, were instrumental in the birth of my interest in this topic and have been faithful and encouraging colleagues and informants in the paper's long gestation. Professor Walter Goldfrank, University of California, Santa Cruz, also has graciously encouraged this project from its earliest stages. Dr. Markku Wilenius, University of Turku, whom I encountered by chance at a meeting of the American Sociological Association, was gracious in sharing materials from his personal Ahlstrom family archives. Professor Jussi Raumolin, University of Helsinki, kindly sent copies of his published materials, helping me commence this research. Officers and staff of Finnish and Swedish organizations and institutions too numerous to name here were universally friendly and supportive. Professors John Bellamy Foster, University of Oregon and Christopher Chase-Dunn, Johns Hopkins University, and an anonymous reviewer for the Journal of World Systems Research provided helpful comments on previous drafts. Financial assistance was received from the Australian-American Educational Foundation (Fulbright Commission); the University of California; the Switzer Foundation; the Centre for Resource and Environmental Studies, Australian National University; and Washington State University. The views expressed here are the author's alone.

2. Sonnenfeld (1996). For extended discussions of internal conditions and dynamics in Indonesia and Thailand, respectively, see Sonnenfeld (1996b; 1998a); see also Sonnenfeld (1998b).

\section{Interview, August 1994.}

4. Labor training and availability is, however, very much an issue in peripheral countries, as they must continually fight brain drain of talented local engineers and technicians to higher-waged areas of the world, as well as insufficient development of advanced training institutions. Advanced human resource development and retention are of 
necessity major focuses of newly industrializing countries' economic development efforts.

5. The history of relations between the two countries goes back centuries. In the 18 th century, Finland was under Swedish rule. Many social and economic ties remain between the two neighbors.

6. At the end of the 20th century, Finland is benefiting once again by its geographic proximity to Russia. As the Russian economy and society continues its chaotic gyrations, Finland has become a reliable source of raw materials, business services, consumer goods, and even a favored tourist destination for its neighbors (Ibrahim 1998).

7. In May 1998, Finland changed its definition of unemployment to bring it into accord with that of the European Union. Finland's official unemployment rates dropped 1-2 per cent as a result (see Statistics Finland 1999). Data for 1981-84 in Figure 2 reflect the old definition; for 1985-98, the new definition.

8. The availability of large quantities of raw materials as a positive condition for economic development is consistent with (Gershenkron 1966, cited in Chase-Dunn and Hall 1997, ch. 5). We know now, after the onset of the "Asian Flu" economic crisis of the late 1990s, that some of Southeast Asia's rapid growth of the previous decade can also be attributed to huge, loosely secured speculative investments in the region by the world's financial community.

9. Here, the structure and organization of these firms are analyzed largely as they were during the Southeast Asian boom from the late 1980s through mid-1990s. In the late $1990 \mathrm{~s}$, spurred in part by their overextension in Asia, all of these firms were involved in mergers (See below).

[Page 39]

Journal of World-Systems Research

10. In turn, the Repola group was "owned by Pohjola (insurance), Metsa-Serla (forest group owned by small-scale farmers), llmarinen (insurance), and Merita (bank)" (Ulvila 1996). In 1997, the Rauma-Repola group merged with the Kymmene Corporation to become UPM-Kymmene; in 1998, UPMKymmene and the Finnish state launched a joint venture between Rauma and the Valmet Corporation, the latter a privatized technology company in which the state retains the largest block of shares. As of this writing, Sunds is a subsidiary of the new Rauma-Valmet corporation, jointly owned by UPMKymmene and the Finnish state. (See below). 
11. Elementally chlorine-free (ECF) pulping technologies were developed in response to concerns about toxic effects of dioxin, a byproduct of using elemental (gaseous) chlorine $\left(\mathrm{Cl}_{2}\right)$ in pulping and bleaching. ECF pulping technologies use chlorine dioxide $\left(\mathrm{ClO}_{2}\right)$, a compound more stable than $\mathrm{Cl}_{2}$, that is nearly as effective in removing lignin from wood pulp. Other contemporary pulping technologies abandon chlorine altogether, using bleaching processes based on molecular oxygen $\left(0_{2}\right)$ or hydrogen peroxide $\left(\mathrm{H}_{2} \mathrm{O}_{2}\right)$ - Such technologies are commonly referred to as totally chlorine-free (TCF).

12. As of this writing, Kværner Pulping was being merged with the Ahlström Corporation's Machinery division. (See below).

13. Data from a presentation at a ceremony dedicating the opening of Kværner Pulping's new Singapore office, April 1994.

14. Ahlström has important historical links with the Jaakko Pöyry group (see below), including through members of the Ehrnrooths, "the richest family in Finland" (Ulvila 1995). Eric Ehrnrooth was one of the founders of Jaakko Pöyry Oy, in the late 1950s. He later went on to head Jaakko Pöyry Engineering (Hass 1978). Jan Ehrnrooth was an executive officer of Ahlström during the 1970s and '80s (Ahlström 1975; 1990; 1991). Another Ehrnrooth, Casimir, was chairman of the Board of the Kymmene Corporation, and a founding member of the Board of Directors of the UPMKymmene Corporation (see below) (UPM-Kymmene 1995). Pöyry's "longrange, ten-year 1967-77 program for A. Ahlström's Varkaus mills ... was followed quite closely and Varkaus became one of Europe's most efficient forest products complexes" (Hass 1978).

15. In 1994, prior to its recent spate of mergers, UPM-Kymmene was the second largest producer of paper in the world, behind only International Paper (Carrere and Lohmann 1996, p. 106).

16. In 1994, Stora and Enso were the fifth and sixth largest paper producers in the world, respectively (ibid.). Again based on 1994 figures, Stora Enso combined would now be the largest paper producer in the world.

17. For a detailed account of Enso's involvement in Indonesian forestry, see Mayer (1996, pp. 219-229).

18. "Oxygen delignification" is a totally chlorine-free pre-bleaching process used to remove lignins -- the chemicals which make unbleached paper brown -- from pulp. Adding this relatively environmentally benign process prior to bleaching facilitates manufacturers' obtaining market-acceptable levels of pulp whiteness and brightness while using less or no elemental chlorine.

19. A "fiberline" is the complete set of technologies used in pulping and bleaching woody raw materials for producing finished pulp.

20. Site visit, August 1994. 


\section{Ibid.}

22. Symbols for the different stages of the pulp bleaching process are as follows: ' $\mathrm{C}$ ' $=$ elemental chlorine $\left(\mathrm{Cl}_{2}\right)$; ' $\mathrm{D}$ '= chlorine dioxide $\left(\mathrm{ClO}_{2}\right)$; 'E'= extraction, with sodium hydroxide $(\mathrm{NaOH}), \mathrm{O}^{\prime}=$ oxygen $\left(0_{2}\right), \mathrm{P}^{\prime}=$ hydrogen peroxide $\left(\mathrm{H}_{2} \mathrm{O}_{2}\right)$; 'H'= hypochlorite $\left(\mathrm{NaOCl}\right.$ or $\left.\mathrm{Ca}[\mathrm{OCI}]_{2}\right)(\mathrm{Smook} 1992)$.

23. Current capacities and bleaching sequences are in parentheses. 'MTH'=mixed tropical hardwoods.

24. Minister Sarwono Kusumatmadja, of Indonesia's Environmental Impact Management Agency (BAPEDAL), declared in December 1993 that all new pulp mills in his country 'had to be ECF or better' (World Paper 1994c). In Thailand, government officials use stringent site-licensing reviews as well as pollution guidelines to minimize new pulp mills' environmental impact.

[Page 40]

Journal of World-Systems Research

\section{References}

Ahlstrom. 1949. A. Ahlstrom Osakeyhtio. Helsinki: A. Ahlstrom Osakeyhtio Co.

Ahlstrom. 1963. A. Ahlstrom Osakeyhtio. Helsinki: A. Ahlstrom Osakeyhtio Co.

Ahlstrom. 1975. "Annual report, 7/1/74-6/30/75." A. Ahlstrom Osakeyhtio, Helsinki.

Ahlstrom. 1990. "Annual report, 1989." A. Ahlstrom Corporation, Helsinki.

Ahlstrom. 1991. "Annual report, 1990." A. Ahlstrom Corporation, Helsinki.

Ahlstrom. 1992. "Annual report, 1991." A. Ahlstrom Corporation, Helsinki.

Ahlstrom. 1993. "Annual report, 1992." A. Ahlstrom Corporation, Helsinki.

Ahlstrom. 1994a. "The Ahlstrom story: a small seedling grows into a big tree." [corporate brochure] A. Ahlstrom Corporation, Helsinki, November.

Ahlstrom. 1994b. "Annual report, 1993." A. Ahlstrom Corporation, Helsinki.

Ahlstrom. 1995. "Annual report, 1994." A. Ahlstrom Corporation, Helsinki. 
Alestalo, Marja. 1993. "Science and the welfare state program: the growth of state activism in Finland." Knowledge and Policy 6(1), Spring, pp. 52-66.

AMS. 1998. "Employment rising nationwide." Gnesta, Sweden: Swedish National Labour Market Board (AMS). [Online.] Available:

http://www.amv.se/ams/rapport eng/iseken9811.html. Access date: April 1, 1999.

APP. 1998a. "Borneo Pulp \& Paper SDN BHD." Singapore: Asia Pulp \& Paper Co. [Online.] Available: http://www.asiapulppaper.com/borneo.htm. Access date: October 22, 1998.

APP. 1998b. "Other information [Itochu]." [press release] Singapore: Asia Pulp \& Paper Co. [Online.] Available: http://www.asiapulppaper.com/f other.htm. Access date:

October 22, 1998 .

APRIL. 1999. "APRIL announces requisite approvals for spin-off of Indorayon received." [press release] Singapore: Asia Pacific Resources International Holdings Ltd. [Online.] Available:

http://biz.yahoo.com/prnews/990115/april_requ_1.html. Access date: March 25, 1999.

Arrighi, Giovanni, ed. 1985. Semiperipheral development: the politics of southern Europe in the twentieth century. Beverly Hills, Calif.: Sage.

Arrighi, Giovanni. 1996. "The rise of East Asia: world systemic and regional aspects." International Journal of Sociology and Social Policy 16 (7/8), pp. 6-44.

Arrighi, Giovanni and Jessica Drangel. 1986. "The stratification of the world-economy: an exploration of the semiperipheral zone." Review 10 (1), pp. 9-74.

[Page 41]

Journal of World-Systems Research

Bergesen, Albert and Laura Parisi. 1997. "Discovering the environment." Journal of World-Systems Research 3 (3), Fall, pp. 364-368. [Online.] Available:

http://jwsr.ucr.edu/.

Bunker, Stephen G. and Paul S. Ciccantell. 1995. "Restructuring markets, reorganizing nature: an examination of Japanese strategies for access to raw materials." Journal of World-Systems Research 1 (3), pp. 1-62. [Online.] Available: http://jwsr.ucr.edu/.

Carrere, Ricardo and Larry Lohmann. 1996. Pulping the South. London: Zed Books. 
Chase-Dunn, Christopher. 1989. Global formation: structures of the world-economy. Oxford, UK: Basil Blackwell.

Chase-Dunn, Christopher K. and Thomas D. Hall. 1997. Rise and demise: comparing world-systems. Boulder, CO: Westview Press.

Chew, Sing C. 1997. "For nature: deep greening world-systems analysis for the 21 st century." Journal of World-Systems Research 3 (3), Fall, pp. 381-402. [Online.] Available: http://jwsr.ucr.edu/.

Cribb, Julian. 1994. "Modern industrial Vikings begin high-tech conquest." The Australian, [Sydney] July 4, p. 11.

Economist, The, 1995. "Finland: mugged by bear." March 25, p. 55.

Edstrom, Sven. 1994. "The closed pulp mill - vision or reality?" in Asian Paper '94 technical papers presented by Kvaerner Pulping.

Enso Oyj. 1998. "Enso Oyj and Advance Agro PCL of Thailand agree on cooperation." [press release] [Online.] Available:

http://www.enso.com/corporate/press/1998/290698eng.html.

Eskeland, Gunnar S. and Ann E. Harrison. 1997. "Moving to greener pastures?

Multinationals and the Pollution Haven Hypothesis." Policy Working Paper, No. 1744.

World Bank, Washington, D.C., January.

Gereffi, Gary and Miguel Korzeniewicz. 1990. "Commodity chains and footware exports in the semiperiphery." Pp. 45-68 in Semiperipheral states in the world-economy, William G. Martin, ed. New York: Greenwood Press.

Gershenkron, Alexander. 1966. Economic backwardness in historical perspective: a book of essays. Cambridge, Mass.: Belknap Press.

Hass, Leonard. 1978. "Jaakko Poyry's years of phenomenal growth." Pulp and Paper International 20 (9), August, pp. 45-48.

[Page 42]

Journal of World-Systems Research

Hellstrom, Eeva and Aarne Reunala. 1995. "Forestry conflicts from the 1950s to 1983."

Research Report, No. 3. European Forestry Institute, Joensuu, Finland. 
Holsti, Kal J. 1986. "Politics in command: foreign trade as national security policy." International Organization 40 (3), Summer, pp. 643-671.

Hornborg, Alf. 1998. "Ecosystems and world systems: accumulation as an ecological process." Journal of World-Systems Research 4 (2), Fall, pp. 169-177. [Online.] Available: http://jwsr.ucr.edu/.

Ibrahim, Youssef M. 1998. "The Finns find glitter in Russia's shadow." [Online.] Available: http://www.nytimes.com.

Jaakko Poyry. 1993a. "Jaakko Poyry consulting review." [corporate brochure] December.

Jaakko Poyry. 1993b. "Jaakko Poyry Group - in brief." [corporate brochure] December. Jaakko Poyry. 1993c. "JP-International worldwide contracting." [corporate brochure] January.

Jaakko Poyry. 1993d. "Know-How Wire 1/93." [corporate magazine] Vantaa, Finland. Jaakko Poyry, 1993e. "Know-How Wire 2/93." [corporate magazine] Vantaa, Finland. Jaakko Poyry. 1993f. "References: consulting assignments; selected recent references."

Jaakko Poyry. 1993g. "References: experience in Asia Pacific."

Jaakko Poyry. 1993h. "References: experience in non-wood fibres."

Jaakko Poyry. 1994a. "Jaakko Poyry Group - address list." February 25.

Jaakko Poyry. 1994b. "Jaakko Poyry's multiclient study services." [advertising flier] Vantaa, Finland, March.

Kerski, Anita. 1995. "Pulp, paper and power: how an industry reshapes its social environment." The Ecologist, July/August.

Kvaerner. 1998a. "Ahlstrom and Kvaerner to merge pulp and paper machinery businesses." December 17.

Kvaerner. 1998b. "Kvaerner announces interim results." September 2.

[Page 43]

Journal of World-Systems Research 
Kvaerner Pulping. 1994. "The front-runner in process technology." [corporate brochure] Kvaerner Pulping AB, Karlstad, Sweden, March.

Laakso, Aku-Pekka. 1998. "Finnish industry: a modern day Cinderella story." [Online.] Available: http://virtual.finland.fi/finfo/english/teollisuus.html.

Leonard, Jeffrey H. 1988. Pollution and the struggle for the world product: multinational corporations, environment, and international comparative advantage. Cambridge, UK: Cambridge University Press.

Lindstrom, Lars-Åke. 1999. Personal communication, February 9.

Logan, John R, and Harvey Molotch. 1987. Urban fortunes: the political economy of place. Berkeley: University of California Press.

Marchak, M. Patricia. 1995. Logging the globe. Montreal: McGill-Queens University Press.

Mayer, Judith Hannah. 1996. "Trees vs, trees: institutional dynamics of indigenous agroforestry and industrial timber in West Kalimantan, Indonesia." Ph.D. Thesis, University of California, City and Regional Planning, Berkeley.

Meadows, Donald G. 1995. "Indonesia: emerging as pulp and paper production giant." Tappi Journal 78 (6), June, pp. 43-49.

Nasman, Lars and Lars-Åke Lindstrom. 1994. "A decade of technological change in kraft pulping focusing on emissions, quality and operating costs." [pamphlet] Sunds Defibrator, Sundsvall, Sweden, April.

Nation, The. 1998a. "Finland's Enso joins pulp maker [Advance Agro]." Bangkok: [Online.] Available:

http://203.146.51.4/nationnews/1998/199806/19980630/28150.html. Access date: October 19, 1998 .

Nation, The. 1998b. "Two foreign firms take 25.4\% of AA [Advance Agro]." Bangkok: [Online.] Available:

http://203.146.51.4/nationnews/1998/199809/19980929/32398.html. Access date:

October $19,1998$.

OECD. 1989a. OECD Economic Surveys: Finland, 1988/1989. Paris: Organisation for Economic Co-Operation and Development. 
OECD. 1989b. OECD Economic Surveys: Sweden, 1988/1989. Paris: Organisation for Economic Co-Operation and Development.

OECD. 1991a. OECD Economic Surveys: Finland, 1990/1991. Paris: Organisation for Economic Co-Operation and Development.

OECD. 1991b. OECD Economic Surveys: Sweden, 1990/1991. Paris: Organisation for Economic Co-Operation and Development.

OECD. 1992a. OECD Economic Surveys: Finland, 1991/1992. Paris: Organisation for Economic Co-Operation and Development.

[Page 44]

Journal of World-Systems Research

OECD. 1992b. OECD Economic Surveys: Sweden, 1991/1992. Paris: Organisation for Economic Co-Operation and Development.

OECD. 1993. OECD Economic Surveys: Finland, 1992-1993. Paris: Organisation for Economic Co-Operation and Development.

OECD. 1994. OECD Economic Surveys: Sweden, 1993-1994. Paris: Organisation for Economic Co-Operation and Development.

OECD. 1995. OECD Economic Surveys: Finland, 1994-1995. Paris: Organisation for Economic Co-Operation and Development.

Raumolin, Jussi. 1984. "The world economy of forest products and the comparative study of the development impact of the forest sector." Pp. 188-211 in Yearbook 1983/1984, Finnish Society for Economic Research, ed.

Raumolin, Jussi. 1990. "Restructuring and internationalization of the Finnish forest, mining and related engineering industries." Pp. 8-22 in Unfamiliar territory: the reshaping of European geography, Michael Hebbert and Jens Christian Hansen, eds. Aldershot, UK: Avebury.

Raumolin, Jussi. 1991. "The transfer and creation of technology in the world economy with special reference to the mining and forest sectors." Pp. 127-150 in World industrial restructuring and north-south cooperation, K. Kiljunen and R.M. Avakov, eds. Helinski: University of Helsinki. Institute of Development Studies. 
Raumolin, Jussi. 1992. "The diffusion of technology in the forest and mining sector in Finland: the shift from the object to the subject of transfer of technology." in Mastering technology diffusion - the Finnish experience, S. Vuori and P. Yla-Anttila, eds. Helinski: ETLA (The Research Institute of the Finnish Economy).

Raumolin, Jussi. 1993. "Ahlstrom: shift from forest products company to environmental technology." Discussion Papers, No. 458, ETLA (The Research Institute of the Finnish Economy), Helinski, December 27.

Reuters News Service. 1994a. "Finland: Rauma divisions record improved order backlogs." June 21.

Reuters News Service. 1994b. "Thailand: Phoenix chief responds to Globex ad campaign." June 10.

Reuters News Service. 1999. "Asia Pulp to reduce debt-to-equity ratio." Singapore: [Online.] Available: http://biz.yahoo.com/rf/990408/d.html. Access date: April 8, 1999.

Smook, Gary A. 1992. Handbook for pulp and paper technologists. 2nd edition. Vancouver, Canada: Angus Wilde Publications.

[Page 45]

Journal of World-Systems Research

Sonnenfeld, David A. 1996a. "Greening the tiger? Social movements' influence on the adoption of environmental technologies in the pulp and paper industries of Australia, Indonesia, and Thailand." Ph.D. Thesis, University of California, Sociology, Santa Cruz, Calif.

Sonnenfeld, David A. 1996b. "Social movements, environment, and technology in Indonesia's pulp and paper industry." Asia Pacific Viewpoint 39 (1), April, pp. 95-110.

Sonnenfeld, David A. 1998a. "From brown to green? Late industrialization, social conflict, and adoption of environmental technologies in Thailand's pulp and paper industry." Organization and Environment 11 (1), March, pp. 59-87.

Sonnenfeld, David A. 1998b. "Logging v recycling: problems in the industrial ecology of pulp manufacturing in South-East Asia." Greener Management International (22), Summer, pp. 108-122.

Statistics Finland. 1996. "Employment statistics." Helsinki: [Online.] Available: http://www.stat.fi. 
Statistics Finland. 1999a. "Finland in figures: unemployment." Helsinki: [Online.] Available: http://www.stat.fi/tk/tp/tasku/tyol2en.html. Access date: April 1, 1999.

Statistics Finland. 1999b. "Harmonised statistics on unemployment from Statistics Finland and the EU." [press release] Helsinki: [Online.] Available:

http:/www.stat.fi/tk/tp tied/tiedotteet/v98/1087ele.html. Access date: April 8, 1999.

Statistics Sweden. 1996. "Employment statistics." [Online.] Available:

http://www.scb.se.

Stora Enso Oyj. 1998. "Stora Enso started operation." [press release] [Online.] Available: http://www.storaenso.com/presscenter/press 1998/231298.html.

Sunds Defibrator. 1993. "Project report: Union Camp bleaching line for C-Free Pulp." Sundsvall, Sweden, May.

Sunds Defibrator, 1994a. "Chemical Pulping News." [newsletter] Sundsvall, Sweden, April.

Sunds Defibrator. 1994b. "Processing of nonwood plants." [pamphlet] Sunds Defibrator, Sundsvall, Sweden, November.

Sunds Defibrator. 1994c. "SuperBatch: the most advanced cooking technology." [promotional brochure] Sundsvall, Sweden, January.

Ulvila, Marko. 1994a. Indonesian selluloosateollisuus: Suomalaiset mukana sademetsien havityksessa (The Indonesian pulp industry: Finland's role in destroying the rainforest). Translated by Illka Lakanemien. Tempere, Finland: Ymparisto ja Kehitys (Coalition for Environment and Development).

Ulvila, Marko. 1994b. Personal communication, August 29.

Ulvila, Marko. 1995. Personal communication, June 2.

Ulvila, Marko. 1996. Personal communication, March 18.

[Page 46]

Journal of World-Systems Research

UPM-Kymmene. 1995. "Kymmene Corporation and Repola Corporation to merge." [press release] [Online.] Available: 
http:/handout.partnergroup.com/upm/news/kymrep.html.

Access date: April 2, 1999.

UPM-Kymmene. 1997. "Agreements signed in UPM-Kymmene and APRIL alliance." [press release] [Online.] Available:

http:/handout.partnergroup.com/upm/news/agreeme.html.

UPM-Kymmene. 1998. "Merger of Rauma and Valmet." [press release] [Online.]

Available: http:/handout.partnergroup.com/upm/news/raumavalınet.html.

Virtual Finland. 1998. "Pulp and paper industry mergers." [Online.] Available: http://virtual.finland.fi/news.

Wallerstein, Immanuel. 1979. The capitalist world-economy. Cambridge, UK:

Cambridge University Press.

Wallgren, Thomas. 1995. "Forest colonialism: behind development aid." in Behind the forests, Riitta Vaismaa, ed. Helsinki: Vihrea Sivistys - ja Opintokeskus/Green Cultural Education Centre. [Online.] Available: http:/www.helsinki.fi/ ajneuvon/dodo,html.

Wilenius, Markku. 1999. Personal communication, January 13.

World Paper. 1994a. "Cigarettes to finance pulp mill," 219 (10). Benn Publications, Tonbridge, Kent, UK, October , p. 13.

World Paper. 1994b. "Enso to start Indonesian forest project." 219 (7/8). Benn

Publications, Tonbridge, Kent, UK, July/August, p. 14.

World Paper. 1994c. "Indonesia set to ban chlorine." 219 (7/8). Benn Publications, Tonbridge, Kent, UK, July/August , p. 14.

World Paper. 1995. "Enso enters joint wood project." 220 (3). Benn Publications, Tonbridge, Kent, UK, March , p. 12.

[Page 47]

Journal of World-Systems Research 